\title{
The Furopean Context of the Group Insurance Contract
}

\begin{abstract}
The entirety of norms on the relations connected with conclusion and performance of insurance contracts make up economic insurance law. Because of its objective homogeneity, it is generally treated as a separate branch of law. From the dogmatic perspective, its permanent element are group insurance contracts. However, the results of a comparative law research allow to draw the conclusion that in a substantial number of legal systems the term "group insurance" is not to be found in normative acts. In the literature, multiple attempts were made to expound the legal nature of the group insurance contract. Still, there is no consensus as to the nature of the legal relationship arising from conclusion of a group insurance contract. The article concerns the proposal of normative regulation of group insurance contract.
\end{abstract}

Keywords: group insurance contract, insurance law, partial groups, extended groups

\section{Sources of generally applicable law governing the group insurance contract}

The entirety of norms on the relations connected with conclusion and performance of insurance contracts make up economic insurance law. Because of its objective homogeneity, it is generally treated as a separate

a) Dr hab., prof. UŚ, University of Silesia in Katowice. 
branch of law. ${ }^{1}$ From the dogmatic perspective, its permanent element are group insurance contracts. However, the results of a comparative law research allow to draw the conclusion that in a substantial number of legal systems the term "group insurance" is not to be found in normative acts. $^{2}$ Even in the systems recognising the need to specifically regulate the group insurance contract, the prevalent tendency is to regulate this subject matter rudimentarily.

One of the few exceptions to that rule is France, where group insurance attracted special attention of the legislator. French insurance law is composed of a number of legislative acts, ${ }^{3}$ which include multiple solutions distinctive against the background of other European legislations. Among solutions specific almost exclusively to French law, one can point also to the extensive regime of group insurance contracts. ${ }^{4}$ Complications following from the application of those provisions are subject to detailed doctrinal discussion.

The contemporary catalogue of sources of insurance law constitutes a very extensive system of interrelated normative acts. One may speak of coherent statutory solutions only in case of one of the types of collective insurance agreements, namely the group insurance contract. Other collective insurance contracts do not form any homogeneous category and are characterised by the absence of coherent systemic solutions.

The basic legislative act covering problems of insurance law is the Insurance Code (hereinafter: CA). ${ }^{5}$ Its field of application ratione personae precludes recourse to the solutions envisaged in the Code in regard to contracts in which the party affording insurance protection is an entity other than joint-stock company pursuing insurance activities. ${ }^{6}$ The provisions of the Code do not apply to contracts concluded by mutual insurance societies or social security institutions. The Insurance Code does not govern insurance law relationships concluded with the involvement of such entities. ${ }^{7}$ This gap, however, is filled by other codes: the Mutual

${ }^{1}$ E. Kowalewski: Prawo ubezpieczeń gospodarczych. Bydgoszcz-Toruń 2006, pp. $84-85$.

${ }^{2}$ L.D. Loacker: Informed Insurance Choice?: The Insurers Pre-Contractual Information Duties in General Consumer Insurance. Cheltenham 2015, p. 226.

${ }^{3}$ M. Bigot-Gonçalves: Les assurances de groupe. Aix-en-Provence 2009, p. 49.

${ }^{4}$ Ibidem, p. 22.

${ }^{5}$ CA - French Insurance Code (Code des assurances; JO 1978, p. 1088, amended).

${ }^{6}$ L. Mayaux, in: Traité de Droit des assurances. Tome 4. Les assurances de personnes. Ed. J. Bigot. Paris 2007, p. 640.

${ }^{7}$ M. Bigot-Gonçalves: Les assurances de groupe..., p. 20. 
Insurance Code (Code de la mutualité) ${ }^{8}$ and the Social Security Code (Code de la sécurité sociale) $)^{9}$.

Beside the Insurance Code, the foundation of the modern legislation on collective group agreements, as a wider category covering among others group insurance contracts, is laid by two Acts of 31 December 1989, namely the Act No. 89-1009 reinforcing the safeguards of persons insured against certain types of risk ${ }^{10}$, referred to as loi Evin ${ }^{11}$, and the Act No. 89-1014, adjusting the Insurance Code to the opening of the European market ${ }^{12}$, referred to as loi Bérégovoy.

Originally, the provisions of Title IV of Book I CA were classified as default norms. Under the Regulation of 30 January $2009^{13}$, the rule of Art. L. 111-2 CA was amended so that the provisions of Book I Title IV of the Code, governing group insurance contracts, were given the status of mandatory provisions (ius cogens $)^{14}$. Under the version currently in force of Art. L. 111-2 CA, the provisions of Book I Titles I, II, III and IV of the Code may not be modified by the intention of the parties. However, the legislator stipulates that the said principle does not relate to provisions which expressly provide for such eventuality and which were exhaustively listed in Art. L. 111-2 CA. It is significant that the norm under Art. L. 111-2 CA does not list as default norms any of the provisions of Title IV of Book I of the Code. ${ }^{15}$ The mandatory character of the rules devoted to group insurance contracts should be of no surprise. Bearing in mind the limited possibility of members of the group of insured parties to influence the contents of the insurance contract, granting extensive contractual freedom to the parties of such contracts

8 See:http://www.legifrance.gouv.fr/affichCode.do?cidTexte=LEGITEXT000006074067 (accessed: 1.07.2015).

9 See: http://www.legifrance.gouv.fr/affichCode.do?cidTexte=LEGITEXT000006073 189 (accessed: 1.07.2015).

10 Act No. 89-1009 of 31 December 1989 reinforcing the safeguards of persons insured against certain types of risk (La loi n 89-1009 du 31 décembre 1989 renforçant les garanties offertes aux personnes assurées contre certains risques, JO du 2 janvier 1990).

${ }^{11}$ D. Rigaud, P. Baron, X. Pig naud: Le prévoyance collective des salariés et la loi Evin. "Droit social" 2009, no. 4, p. 465.

12 Act No. 89-1014 of 31 December 1989 adjusting the Insurance Code to the opening of the European market (Loi n 89-1014 du 31 décembre 1989 portant adaptation du code des assurances à l'ouverture du marché européen, $\mathrm{JO}^{\circ} 2$ du 3.01.1990).

${ }^{13}$ Ordonnance $\mathrm{n}^{\circ}$ 2009-106 du 30 janvier 2009 portant sur la commercialisation des produits d'assurance sur la vie et sur des opérations de prévoyance collective et d'assurance, JORF no, 0026 of 31 January 2009, p. 1838 et seq.

14 J.C. Ponge: Les sanctions en droit des assurances. Paris 2010, p. 57.

15 See A. Bzdyń: Ubezpieczenia grupowe we francuskim „code des assurances”. In: Ubezpieczenia grupowe na życie a prawo zamówień publicznych. Ed. E. Kowalewski. Toruń 2011, p. 200. 
could infringe the interests of the collectivity covered by insurance protection.

It must be noted that the legislator introduces as well specific solutions for group insurance contracts outside Book I Title IV of the Code. Under art. L. 132-7 CA, life insurance is invalid if the insured party committed suicide in the first year of the term of such agreement. This norm, however, does not apply to group insurance contracts ${ }^{16}$ mentioned in Art. L. 141-1 CA signed by the parties listed in Art. L. 141-6 CA. Pursuant to Art. L. 132-23 CA, in group insurance contracts in which the risk relates to the end of the working life, including supplemental insurance for public officers, it is inadmissible to stipulate the right to surrender a policy.

French law is characterised by a tendency to enact special provisions for generic categories of group insurance. The Act No. 2003-775 of 21 August 2003 introducing a pension reform ${ }^{17}$, referred to as loi Fillon, established the normative framework for the operation of group insurance contracts serving as pension insurance. Another area which attracted the legislator's special attention was the sector of elective insurance of employees and persons performing work on a basis other than employment contract $^{18}$.

On the contrary, a feature characteristic of German law is the existence of only rudimentary rules on group insurance. This may surprise, bearing in mind that the currently applicable Act on the insurance contract entered into force only on 1 January $2009^{19}$. The German legislator decided to introduce a new legislative act in view of the fact that adaptation to today's challenges of the Insurance Law Act which had been in force for nearly 100 years would not be possible by implementing minor legislative corrections. ${ }^{20}$ The attitude of the legislator in itself to the conception of reforming insurance law augured far-reaching review of the regime of insurance relationships.

However, in the said Act, there is no comprehensive set of norms governing group insurance contracts. What is more, the German legislator did not decide to formulate a definition of group insurance although that

${ }_{16}$ This solution, however, is criticised in the doctrine. See G. Courtieu: Un suicide raté ou le législateur se tire une balle dans le pied. "Gazette du Palais" 1999, 8-9 janvier, p. 2.

${ }^{17}$ La loi du 21 août 2003 portant réforme des retraites, JO du 22 août 2003.

${ }_{18}$ M. Bigot-Gonçalves: Les assurances de groupe. Aix-en-Provence 2009, pp. $40-41$.

${ }^{19}$ German Act on the insurance contract of 23 November 2007 (Versicherungsvertragsgesetz. "Das Bundesgesetzblatt", p. 2631).

${ }_{20}$ See H. Heiss: Proportionality in the new German insurance contract act 2008. "Erasmus Law Review" 2012, vol. 5, p. 105 and the legislative materials cited therein. 
term is used in the Act. The distinctive feature of the German legislative framework of group insurance is the legislator's care for the insured parties being guaranteed the right to continue insurance. Only in this context does the new Act mention group insurance contracts $(\S 206$ and $\S 207 \mathrm{VVG})$.

The few legal systems in which the legislator decided to introduce a definition of the group insurance contract include as well Scandinavian countries. In Swedish law ${ }^{21}$, it is defined as insurance contract under which protection is afforded to a group of persons ${ }^{22}$. The provision of $\S 2$ item 6 of the Finnish Act ${ }^{23}$ defines the group insurance contract as an insurance contract in which protection is or may be afforded to members of a group specified in the insurance contract. In Norwegian law, ${ }^{24}$ in turn, the group insurance contract is defined as insurance in which the rights and obligations of the group members are defined by an agreement concluded by the policyholder in the name or on behalf of the group members ( $1-2$ letter $d$ of the Norwegian Act on the insurance contract).

A controversial method of regulating group insurance contracts was used by the Turkish legislator in the new Commercial Code, ${ }^{25}$ applicable as of 1 July 2012. It must be noted that the Turkish regime is strongly inspired by the works on the uniform insurance contract law, ${ }^{26}$ carried out with the use of comparative law research. Among the provisions on the insurance contract (Arts. 1401-1520 TTK), there is only one article on group insurance (Art. 1496 TTK). Within the framework of that provision, the legislator attempted, at least partially, to regulate such issues which stir doubts of insurance law experts, starting from the definition of group insurance, and ending with the question of individual continuation of insurance protection. It should be remarked that the legislator recognises the need to regulate insurance contracts more extensively. Under the delegation of legislative powers provided for in Art. 1496(5)

${ }^{21}$ Swedish Act on the insurance contract 2005, Försäkringsavtalslag (SFS 2005: 104), available at: https://www.riksdagen.se/sv/dokument-lagar/dokument/svensk-forfatt ningssamling/forsakringsavtalslag-2005104_sfs-2005-104 (last accessed: 5 April 2019).

${ }^{22}$ More in J. Hjalmarsson: The Swedish Insurance Contract Act 2005 - an overview. "Nordisk forsikringstidsskrift" 2008, no. 1, pp. 91-92.

${ }^{23}$ Finnish Act on the insurance contract No. 543/1994 of 28 June 1994, Vakuutussopimuslaki 28.6.1994/543, Författningssamling 1450 (accessed: 5.04.2019).

${ }^{24}$ Norwegian Act on the insurance contract, Act of 16 June 1989 No. 69, available at: http://www.aida.org.uk/pdf/NORWAY\%20Insurance\%20Contracts\%20Act\%201990 -2009.pdf (accessed: 5 .04.2019).

${ }_{25}$ Türk Ticaret Kanunu, 13.1.2011, No.: 6102, "Resmi Gazete" 14.2.2011, No. 27846.

${ }^{26}$ K. Atamer: New Turskish Insurance Contract Law, p. 5, available online at: http://www.aida.org.uk/pdf/Turkish\%20Insurance\%20Contract\%20Law.pdf (accessed: 8.07. 2015). 
TTK, questions expressly listed by the legislator (including but not limited to the surrender of policy or notification requirements in group insurance) and - which may surprise - "other questions material to the group insurance contract" will be regulated in secondary legislation. It does not seem that such legislative technique deserves to be emulated.

Poland, on the contrary, is an example of a legal system in which the legislator does not pay attention to group insurance. Group insurance contracts are concluded under the principle of freedom of contract (Art. $353^{1} \mathrm{CC}$ ) and according to the mandatory provisions contained in Book III Title XXVII of the Civil Code. ${ }^{27}$

In Portuguese law, besides specific legislation concerning life insurance, general rules regarding group insurance laid down in the legal framework of the insurance contract (Articles 76-9028) apply to group life insurance. As such, group life insurance can either be contributive or non-contributive. Group life insurance cover risk related to a group of people who are linked to the policyholder for a certain reason not related with insurance - the group may be composed, for example, of the employees of a certain company, the lawyers of a bar association, or the teachers of a certain school.

Contributive group life insurance contracts should regulate surrender in accordance with the contribution of the insured person (Article $194^{29}$ ). In group life insurance the nomination of the beneficiary is made by the insured person - in all other aspects the rules on the nomination of the beneficiary apply also to group life insurance contracts (Article $81^{30}$ ).

In Spanish law, according to the number of insured, personal insurance can be either individual insurance or group insurance as prescribed by Article 81 of the LCS. ${ }^{31}$ This provision states that contracts may be subscribed with the reference to risk related to one person or to a group of them.

Indeed, Article 81 of the LCS expressly allows the contract to be subscribed for the benefit of a group of persons and imposes the only require-

${ }^{27}$ J. Handschke, B. Kęszycka, E. Kowalewski: Problematyka grupowych ubezpieczeń na życie $w$ świetle znowelizowanych przepisów k.c. o umowie ubezpieczenia. Spór o intencje ustawodawcy. „Wiadomości Ubezpieczeniowe” 2007, No. 7-8, p. 5; M. Serwach, J. Kliszcz: Grupowe ubezpieczenie na życie w świetle prawa, doktryny i praktyki ubezpieczeniowej. „Prawo Asekuracyjne” 2010, No. 2, p. 33.

${ }^{28}$ Decreto-Lei n. $^{\circ} 72 / 2008$ de 16 de Abril, Estabelece o regime jurídico do contrato de seguro, available online at: https://data.dre.pt/eli/dec-lei/72/2008/04/16/p/dre/pt/html (accessed: 20.03.2020).

${ }^{29}$ Decreto-Lei n. ${ }^{\circ}$ 72/2008 de 16 de Abril.

${ }^{30}$ Ibidem.

${ }^{31}$ Ley 80/2005, de 8 de octubre de Contrato de Seguro, BOE-A-1980-22501. 
ment that the group be identified by a common characteristic different from the insurance's purpose ${ }^{32}$.

\section{The concept of group insurance}

As compared to individual insurance, in which all risks focus, in principle, around one party, in the collective type of insurance contract the risk is spread over a certain population (group) of insured parties. As a consequence, the collective insurance contract is an example of multiplication of the number of persons involved in the insurance relationship.

This thought is reflected in Polish literature. ${ }^{33}$ It is generally accepted that insurance contracts are divided according to the number of persons covered by insurance protection into individual and collective insurance. ${ }^{34}$ The dissimilarities between individual and collective insurance contracts are manifest, among others, in respect of the following questions: conclusion of the insurance contract, legal nature of the insurance contract, the scope of insurance protection, methods of extending insurance protection during the insurance relationship to such persons that originally, upon conclusion of the insurance contract, did not enjoy protection, as well as insurance administration or assessment and selection of risk. ${ }^{35}$

The discussed type of insurance contract must be differentiated from such constructions in which several insurers grant protection against the agreed risk. This formula is referred to as coinsurance agreement. The classical type of group insurance does not cover as well contracts concluded by several policyholders for the protection against risk of destruction or loss of common property.

Although the collective insurance formula is a widespread solution in commercial practices, only a few legal systems contain a regime govern-

32 J.B. Grau, N.L. Chiner, J.O. Iglesia: Insurance law in Spain. Wolters Kluwer 2014, p. $182-183$.

${ }^{33}$ See M. Olszewik: Ubezpieczenia grupowe. In: Ubezpieczenia życiowe. Ed. O. Doan. Warszawa 1995, p. 94.

${ }^{34}$ Cf. J. Handschke, B. Kęszycka, E. Kowalewski: Problematyka grupowych ubezpieczeń na życie w świetle znowelizowanych przepisów k.c. o umowie ubezpieczenia. Spór o intencje ustawodawcy. „Wiadomości Ubezpieczeniowe” 2007, No. 7-8, p. 3.

${ }_{35}$ More from the economic perspective in K. Eyskawa: Grupowe ubezpieczenia na zycie $z$ funduszem kapitałowym $w$ systemie zabezpieczenia emerytalnego $w$ Polsce. Warszawa 2007, pp. 153-156. 
ing such contracts. It is even less frequent for legislators to define the concept of group or collective insurance. ${ }^{36}$

It is significant that, despite the absence of definition of the insurance contract itself, the French legislator introduced a definition of group insurance contracts. ${ }^{37}$ Originally, the group insurance contract was rendered under Art. R. 140-1 CA as "insurance of a group of people with similar properties and subject to the same rules on the protection from risks relating to the length of life, incapacity to work, reimbursement of medical, pharmaceutical or surgical costs, or payment of a benefit in connection with maternity." 38

The currently applicable version of the definition was introduced under the provisions of the Act No. 89-1014 of 31 December 1989, as a part of Art. L. 140-1 CA, ${ }^{39}$ renamed by the Act of 26 July $2005^{40}$ to Art. L. 141-1 CA. ${ }^{41}$ Under Art. L. 141-1(1) CA the group insurance contract is a contract concluded by a legal person or natural person in charge of an enterprise for the purpose of such contract being acceded by persons who meet specific criteria laid down in the contract. Insurance protection may cover risks relating to the length of human life, violation of bodily integrity or maternity, risks relating to the inability to work,

${ }^{36}$ H. Heiss: Report of the Commission's Expert Group on European Insurance Contract Law. Part II. Differences in Insurance Contract Laws and Existing EU Legal Framework, http://ec.europa.eu/justice/contract/files/expert_groups/report_on_sec tion_2_final_en.pdf (accessed: 21.06.2014), p. 14 .

${ }^{37}$ It should be mentioned that in Belgian insurance law, which was developed under strong inspiration of French law, there is also no general definition of collective insurance contracts. Nevertheless, the provision of Art. 138 bis- $1 \S 2$ of the Belgian. LCA (Belgian Act on the insurance contract of 25 June 1992 (loi du 25 juin 1992 sur le contrat d'assurance terrestre, 1992-06-25/32, p. 18283) defines the contract for the insurance of risks relating to health of the insured parties as contract concluded by one or a number of policyholders for account of persons with professional connections to the policyholder at the time of concluding the contract. C. Devoet: Les caractères de l'assurance maladie (privée). Liber amicorum Jean-Luc Fagnart. Eds. J. Rogge, M. Regout, F. Longfils. Louvain-la-Neuve 2008, p. 119; more on the collective insurance contract in Belgian law in A. La men s: Les assurances complémentaires contre la maladie. In: Les assurances de l'entreprise. Bruxelles 1994, pp. 409-422.

${ }^{38}$ M. Bou médienne: La place de la loi et du contrat dans la garantie du droit à la protection sociale de 1945 à nos jours, vol. 2. Paris 2003, p. 397.

${ }^{39}$ Act No. 89-1014 of 31 December 1989 adjusting the Insurance Code to the opening of the European market (Loi n 89-1014 du 31 décembre 1989 portant adaptation du code des assurances à l'ouverture du marché européen, JO nº 2 du 03/01/1990).

${ }^{40}$ La loi no 2005-842 du 26 juillet 2005, pour la confiance et la modernisation de l'économie, JORF n 173 du 27 juillet 2005, p. 12160.

${ }^{41}$ More on the legislative amendments within Book I Title IV CA in M. Bou médienne: La place de la loi et du contrat dans la garantie du droit à la protection sociale de 1945 à nos jours, vol. 2. Paris 2003, pp. 397-398. 
disability or unemployment. According to Art. L. 141-1(2) CA, all persons acceding to the group insurance contract must have an identical connection with the policyholder.

In relation to the formula of Art. R. 140-1 CA, the French legislator widened the objective scope of risks that may be covered by group insurance contracts. ${ }^{42}$ It should be noted that the legislator, within the framework of Art. R. 140-1 CA, avoided denominating particular parties to the insurance relationship. Presently, it is clearly indicated that the group insurance contract is concluded by the policyholder (souscripteur) for the purpose of ensuring protection to the acceding parties (adhérents) who are connected with the policyholder by the same type of relationship, which also was not expressly required under art. R. 140-1 CA.

The introduction of legal definition of the group insurance contract in French law did not remove the doubts voiced in the doctrine as to the legal nature of such contracts. The text of the Insurance Code in itself is still insufficient to account for the juridical construction of group insurance. Based on the textual layer of the Act, it is impossible to establish whether a person acceding to the insurance is a party of the insurance agreement concluded by the policyholder or if such person is connected with the insurer by another contractual relationship. ${ }^{43}$

In French literature ${ }^{44}$ it is pointed out that the introduction in the Insurance Code of the provision of Art. L. 141-1 CA was not intended to specify the legal nature of group insurance contracts. On the other hand, this provision serves to differentiate between the scopes of application of the specific normative acts on the problems of collective insurance. ${ }^{45}$ Under the French legislative regime, the mutual relation between the concepts of collective insurance (assurance collective) and group insurance (assurance de groupe) had remained unclear for a relatively long period of time.

Traditionally, French doctrine identified the concepts of group and collective insurance contract. ${ }^{46}$ Some of the authors, on the other hand, considered group insurance as a type of collective insurance. ${ }^{47}$ Upon introduction in the Insurance Code of the provisions expressly relating

${ }^{42}$ Ibidem, p. 397.

43 J. Bigot, in: Traité de Droit des assurances, t. 3, Le contrat d'assurance. Ed. J. Bigot. Paris 2002, pp. 478-479.

${ }^{44}$ M. Boumédienne : La place..., p. 397.

${ }^{45}$ Loi no 89-1014 du 31 décembre 1989.

${ }^{46}$ M. Demarle: Le notariat de la prévoyance. Paris 1959, p. 34; S. Beaugendre: Contrat d'assistance et activité d'assurance. Paris 2000, p. 241 and the literature cited therein.

${ }^{47}$ J. Kullmann: Les mécanismes juridiques fondamentaux des assurances collectives. "Revue générale du droit des assurances" 1998, no 3, pp. 527 ff. 
to group insurance contracts (assurances des groupes), this view was normatively confirmed and currently it is the prevailing opinion in the French science of insurance law. ${ }^{48}$

It has been noticed in the literature of the subject that, because of the limited number of elements common to collective insurance contracts, this term should refer to a specific method of concluding insurance contracts. ${ }^{49}$ Collective insurance is even recognised as a "technique of concluding insurance contracts" ${ }^{10}$ by means of which, within one insurance relationship, a wider circle of persons in a similar life situation become connected.

Because of the difficulties in the specification of the legal nature of collective insurance contracts and absence of any extensive statutory framework, it is extremely tempting to treat the contract as sui generis construction, which however makes it harder to identify the legal regime governing the consequences of such contract. ${ }^{51}$

It seems that two solutions are plausible. The first proposal assumes application of the provisions of Book I Title IV CA which are dedicated to group insurance contracts sensu stricto. The other hypothesis is based on the assumption of the need for appropriate application of the provisions governing the rights and obligations of the parties to an individual insurance contract and provisions of the general part of the French Civil Code.

The former solution is to be justified primarily by the lack of any express prohibition to apply the provisions of Book I Title IV CA to insurance contracts not specified in Art. L. 141-1 CA. ${ }^{52}$ This argumentation, however, is not convincing. First, the systemic interpretation of the Code leads to the conclusion that the provisions of Book I Title IV CA apply exclusively to the contracts specified in Art. L. 141-1 CA, which article opens Title IV. Second, since the definition of group insurance contract under Art. L. 141-1 CA delimitates the scope of application of

${ }^{48}$ L. Mayaux, in: Traité de Droit des assurances..., p. 636. The concviction about the admissibility to use interchangeably the terms group insurance (assurance de groupe) and collective insurance (assurance collective) is still widespread in Belgian law, in which no clear distinction was made between group and collective insuarance contracts. J.M. Binon: Actualités législatives et jurisprudentielles dans les assurances de personnes. In: Actualités en droit des assurances. Eds. C. Paris, B. Dubuisson. Liège 2008, p. 329.

49 T. Tauran: Les Assurances, Paris 2004, pp. 14-15.

${ }^{50}$ P.D. Saint-Hilaire: Le tiers à l'acte juridique. Paris 2000, p. 179.

51 J. Landel: L'assurance de groupe à la lumière de la jurisprudence récente. "Revue générale des assurances terrestres" 1993, pp. 9-10.

${ }^{52}$ Arguments for such solution are more widely presented in F. Berdot: L'assurance de groupe après les réformes législatives du 31 décembre 1989. "Revue générale des assurances terrestres" 1990 , p. 778. 
the provisions of Title IV, the adoption of the discussed conception would clearly contradict the legislator's intention and deprive such definition of its principal function.

Proponents of the latter view concentrate on the formulation of critical comments to the assumptions outlined above. They indicate, in the first place, that the provisions of Book I Title IV generally refer to personal insurance. Collective insurance, on the other hand, relates predominantly to insurance contracts which would be classified as property insurance. ${ }^{53}$ However, it is difficult to find such view legitimate. Among the risks provided for in Art. L. 141-1 CA one can include also such risks which are specific to damage insurance (risks relating to loss of employment), ${ }^{54}$ which is going to be discussed below.

It should be noted that, in French doctrine, there were postulates to introduce a term which would refer to collective insurance other than group insurance contracts. In the end, however, no such proposal was met with general approval by representatives of the legal science. This is the case since only group insurance contracts have a specific normative regime. Other agreements, that is collective insurance contracts, make a heterogeneous category and, at the time being, there is no legal regime common to all of them. Consequently, there is no need to use the term "collectivity insurance" (assurance de groupement), by which certain authors refer to collective insurance contracts other than the group insurance contract sensu stricto. ${ }^{55}$

In the Polish literature, a considerable group of authors also use inconsistently the terms: singular and individual insurance on one hand, and group and collective insurance on the other, and treat them interchangeably. ${ }^{56}$ There are also authors who attach different meanings to those terms. ${ }^{57}$ It is emphasised that it is incorrect to identify the concepts of collective and group insurance. ${ }^{58}$

${ }^{53}$ H. Groutel, in: Traité du contrat d'assurance terrestre. Ed. H. Groutel. Paris 2008, p. 52; L. Lefebvre, E. le Guilcher: L'ambigu statut des courtiers grossistes. "Lamy Assurances" 2012, no. 198, p. 2-3.

${ }^{54}$ Ibidem, p. 3 and the case-law cited therein.

${ }^{55}$ F. Berdot: L'assurance de groupe. "Revue générale des assurances terrestres" 1980, p. 18.

${ }^{56}$ Cf. W. Warkałło: Prawo ubezpieczeniowe. Zarys wykładu i materiały normatywne. Warszawa 1974, pp. 155 ff.; S. Dmochowski: Ubezpieczenia majatkowe $i$ osobowe ludności. Warszawa 1975, pp. $150 \mathrm{ff}$.

${ }^{57}$ See M. Domagała: Zakres i tendencje rozwojowe ubezpieczeń następstw nieszczęśliwych wypadków. „SU” 1975, vol. II, pp. 209, 212-213; Z.K. Nowakow ski, A. Wasiewicz: Prawo ubezpieczeń gospodarczych. Warszawa-Poznań 1980, p. 285.

${ }^{58} \mathrm{~K}$. Łyskawa: Grupowe ubezpieczenia na życie $z$ funduszem kapitałowym w systemie zabezpieczenia emerytalnego w Polsce. Warszawa 2007, p. 155. 
In older literature, three types of collective insurance were indicated: cumulative insurance, which are individual insurance agreements concluded at the same time by several persons with a view to obtaining a premium discount; class insurance in which the access and entry to the insured class is automatic (e.g. participation in a sports competition), and group (nominal) insurance in which particular members declare their participation. It was assumed that all the above types of insurance constitute group insurance but only the last type are insurance contracts in the strict sense of the word..$^{59}$

In German doctrine, a similar distinction was accepted with regard to collective insurance. Authors identified three types of insurance. First, these were nominal insurance contracts in which a single insurance covered more than one person named in the insurance certificate. Another category were innominate insurance contracts in which one insurance referred to several persons designated not by name but by number, covering all members of a given set, for example, all employees in a given plant or members of a given sports club. In this approach, group insurance differed from innominate insurance inasmuch as it did not necessarily cover all members of a given collectivity (e.g. all personnel of a given employer) ${ }^{60}$

A common feature of the above typologies is the conviction characteristic also of the French legal science that group insurance contracts are a subtype of collective insurance. However, much more doubts arise in the context of laying down a demarcation line between group insurance and the broader category of collective insurance.

Within the scope of collective insurance, insurance of employees and other groups is distinguished. Collective insurance is divided into: group (employee) insurance contracts, assigned the status of "legally identified institutions" in Poland and other countries, and collective (non-employee) insurance contracts - insurance of social groups other than employees (e.g. tourists, school pupils, sportspersons, etc.). ${ }^{61}$

In the doctrine, there are also other proposals for the criteria allowing to specify the meaning of the terms "group insurance" and "collective insurance."

Certain authors, who clearly distinguish between collective and group insurance, claim for example that group insurance is the case only when the entire group takes advantage of the insurance protection on

${ }^{59}$ So writes Z. Szymański: Ubezpieczenia następstw nieszczęśliwych wypadków. Warszawa 1980, p. 118.

${ }^{60}$ More in A. Manes: Versicherungs-Lexikon. Berlin 1924, pp. $283 \mathrm{ff}$.

${ }^{61}$ W. Warkałło: Prawo ubezpieczeniowe. Zarys wykładu $i$ materiały normatywne. Warszawa 1974, p. 200. 
the same terms. They refer only to such insurance contracts as group insurance sensu stricto. ${ }^{62}$

\section{The concept of "group" in group insurance contracts}

In light of the subjective configuration which is characteristic only of collective insurance contracts, special attention should be paid to the understanding of the term "group" in insurance law.

At this point, it is worth referring to thorough investigations on the essence of the concept of "group" in foreign literature.

In French law, the term "group" is generally not to be found in the provisions of the Insurance Code. It is not used in the definition of the group insurance contract under Art. L. 141-1 CA. However, the meaning of that term may be reconstructed on the basis of the normative content of that provision. Under Art. L. 141-1 CA, insurance contract is concluded by the policyholder for the purpose of such contract being acceded by a collectivity of people who meet the criteria specified in the contract. Moreover, each of the persons acceding to the insurance must have connections of the same type with the policyholder (Art. L. 141-1(2) CA). The requirements under items (1) and (2) of Art. L. 141-1 CA allow to determine the range of persons who, at least potentially, may accede to a group insurance. As a result, they delimitate the concept of "group" when read jointly. ${ }^{63}$

Specification of further requirements which must be met by persons interested in accession to the insurance (Art. L.141-1(1) CA) allows to realise the principle of freedom of contract as a part of the relationship between the policyholder and the insurer. Such requirements may be expressed positively in the agreement. Then, their fulfilment by a given person will condition the possibility to accede to the group insurance and gain the status of an insured party. On the other hand, there are no contradictions to defining such requirements negatively. Then, they specify a feature which disqualifies a given person from the possibility of applying for the insurance protection.

Within the range discussed above, the French model corresponds to the solutions developed in German doctrine. Group insurance contracts

${ }^{62}$ E. Stroiński: Ubezpieczenia na życie. Teoria i praktyka. Warszawa 2003, p. 278.

${ }^{63}$ G. Sargos: Le contrat d'assurance de personnes et ses trois principaux codes: analyse comparative et prospective. Paris 2012, p. 26. 
are divided by the provisions of law into partial groups (Teilgruppe) and extended groups (erweiterte Gruppe). If there is a group covered by a group insurance contract within the meaning described above, it is possible to identify its parts under the contract. This involves specification of a limited group of persons according to their general characteristics. It is possible to limit the range of entitled persons within a group by such criteria as age, period of employment with the employer, place of residence or the position held in the hierarchy of a given workplace. A group insurance contract may contain a clause excluding the possibility of the protection covering, for instance, certain employee groups which, because of the character of their work, could expose the insurer to an excessive risk of paying high benefits. Consequently, like in French law, it is possible to limit the range of persons capable of applying for insurance protection by reference to negative criteria. It should be mentioned that in case of extended groups within the framework of group insurance, apart from the insured party, there appear other persons directly enjoying the insurance protection. ${ }^{64}$ These are so called co-insured parties, usually close relatives of the insured party him-/herself, covered by the protection either under the standard agreement or under additional contracts, usually providing for a higher premium. ${ }^{65}$

In the provisions of the French Insurance Code, the meaning of the second prerequisite (Art. L. 141-1(2) CA), referring to the extra-insurance relation between the policyholder and the insured parties, has not been specified. ${ }^{66}$ Analysis of the wording of the provisions of the Insurance Code does not permit any clear answer to the question if there must be a legal relationship or if a factual connection is sufficient between the person acceding to the insurance and the policyholder. ${ }^{67}$ Besides, there are no hints allowing to determine whether the existence of such relation must predate accession to the insurance.

By textual interpretation of the provision of Art. L. 141-1(2) CA, one may formulate the conclusion that such relation must subsist at the time of accession to the contract. On the other hand, the second sentence of Art. L. 141-1 CA does not require that the connection between the in-

${ }^{64}$ F. Herdter: Der Gruppenversicherungsvertrag: Grundlagen und ausgewählte Problemfelder. Karlsruhe 2010, p. 47.

${ }_{65}$ M. Szczepańska: Ubezpieczenia na życie. Aspekty prawne. Warszawa 2008, p. 127.

${ }^{66}$ G. Sargos: Le contrat d'assurance de personnes et ses trois principaux codes: analyse comparative et prospective. Paris 2012, p. 26.

${ }^{67}$ Otherwise in A. Bzdyń: Ubezpieczenia grupowe we francuskim „code des assurances.”In: Ubezpieczenia grupowe na życie a prawo zamówień publicznych. Ed. E. Kowalewski. Torun 2011, p. 201. 
terested parties exist prior to accession to the insurance agreement ${ }^{68}$. In consequence, a question arises if mere notification of the intention to be covered by insurance protection is sufficient for the conclusion of a group insurance contract. At this stage, one may already speak about formation of a specific relation between a group member and the policyholder.

It is essential to correctly read the intention of the French legislator since the conclusion that there must be a legal relationship between the policyholder and the insured parties would significantly restrict the scope of application of the provisions of Book I Title IV CA. For example, necessity of a legal relationship between the policyholder and the insured parties would preclude the possibility of concluding a group insurance contract for the benefit of former employees. At the time of concluding the contract, there would, in fact, be no legal relationship representing the relationship required by the second sentence of Art. L. 141-1 CA. This example is adduced by one of the authors ${ }^{69}$ who draws attention to the admissibility of concluding such type of insurance contract in the context of Art. 4 loi Evin and Art. 14 of the national inter-trade agreement of 11 January 2008. ${ }^{70}$ This kind of doubt is also voiced by representatives of German legal science, for whom the reason to conduct research in this regard are group life insurance contracts for retired employees. ${ }^{71}$

A question that may raise doubts is whether membership in a given structure is in itself sufficient to conclude that the prerequisite under Art. L. 141-1(2) CA has been met. When answering the above question, one should note that the contract under Art. L. 141-1 CA may be concluded by a person running an enterprise. The discussed provision of Art. L. 141-1(2) CA does not require any connection between an insured party covered by group insurance and such enterprise. The French legislator attaches significance only to the relation between the specific persons participating in the relationship formed under a group insurance contract (policyholder and insured parties). There should be no doubt that under the French legislative framework it is insignificant if such connection exists between particular insured parties. ${ }^{72}$

${ }^{68}$ L. Mayaux, in: Traité de Droit des assurances..., p. 632.

${ }^{69}$ G. Sargos: Le contrat d'assurance de personnes et ses trois principaux codes: analyse comparative et prospective. Paris 2012, p. 27.

${ }^{70}$ L'Accord National Interprofessionnel du 11 janvier 2008 sur la modernisation du marché de travail. More on the role of inter-trade agreements and their benefits for former employees in A. Fabre, F. Lefresne, C. Tuchszirer: L'accord du 11 janvier 2008 sur la modernisation du marché du travail. Une tentative d'évaluation. "Revue de l'OFCE" 2008, vol. 4, no 107, p. 8.

${ }^{71}$ See the arguments in A. Wieser: Gruppenversicherungen. Wien 2006, p. 104.

72 M. Bigot-Gonçalves: Les assurances..., p. 19. 
Certain authors, however, are of the opinion that the insured parties may be in a certain relation either with the policyholder himself or with the initiative organised by the policyholder, as long as insurance protection is afforded in connection with such initiative. ${ }^{73}$ Proponents of such interpretation of the provision of Art. L. 141-1 CA use the example of participants in a sports event who need not be connected by any legal relationship with the event's organiser for their effective coverage by the insurance protection afforded under a group insurance contract. ${ }^{74}$ It is sufficient if they are focused "around" the policyholder or a certain undertaking.

In German literature, ${ }^{75}$ a typology of groups is accentuated which, from the point of view of the requirement of group durability, understood as connection between the parties insured under a group insurance and the policyholders, looks similar to the French model.

The first category distinguished by German science are durable groups (Dauergruppe), which imply multiplicity of persons simultaneously connected by a legal relationship intended for a longer period of time. As a consequence, members of such group are subjected to a specific legal relationship. The persons especially predestined for the role of policyholder - group organiser - are employers in relation to employee groups or organisations (associations, political parties, trade unions, etc.) in relation to the groups of their members. ${ }^{76}$

An opposite of a durable group is a short-term group (kurzfristige Gruppe). By this category, one should understand a multiplicity of persons connected by common active or passive, depending on the organiser, participation in an undertaking delimited in time and space. Participants of such undertaking are grouped, within its framework, in a specific factual situation. An example of such group may be participants and viewers of a football match. Purchase of a ticket implies admission by the organiser to participation in the mass event which can be clearly defined in terms of time and space. The concept of short-term group will not apply to mass events open for an unlimited number of people (e.g. procession). For the emergence of a short-term group for the purpose of group insurance, it is only required that a larger number of people connected by a legal relationship with the group organised take part in a mass event which can be delimited in time and space. ${ }^{77}$

${ }^{73}$ G. Sargos: Le contrat d'assurance..., pp. 26-27; L. Mayaux, in: Traité de Droit des assurances..., p. 632.

${ }^{74}$ Ibidem, pp. 632-633.

${ }^{75}$ F. Herdter: Der Gruppenversicherungsvertrag..., p. 43.

76 Ibidem, p. 43.

77 Ibidem, p. 45. 
An interesting solution has been provided for in the Finnish Act of $1994 .{ }^{78}$ The Act defines group insurance as insurance under which insurance protection covers or may cover a group specified in the contract (§2 item 6). The insurance protection subsists independently of the extra-insurance relations between the policyholder and the insured parties. This does not mean, however, that this feature is irrelevant. Under the Finnish Act, there are two separate normative regimes for group insurance contracts: the former, which is basic in nature, and the latter, which applies when the group insurance relates only to a short-term stay at an agreed location or participation in an event lasting no longer than a month (§4).

Comparison of the normative content of the abovementioned legal systems allows to formulate the conclusion that the extra-insurance relation between the insured party and the policyholder required for the subsistence of a group is, in principle, a legal relationship. A factual relationship is a sufficient ground to afford insurance protection if it can be contained within a specific temporal and spatial framework.

In such legal systems in which no connection between the policyholder and the insured parties is required, the requirement of specificity of the group of parties insured within the framework of group insurance is expressed only in that such group should be designated by pointing to a common characteristic feature. Such solution was adopted by the Spanish legislator in Art. 81 of the Act 50/1980 of 8 October 1980 on the insurance contract ${ }^{79}$ stating that a group within the framework of group insurance should be designated by reference to a common characteristic distinguishing such group for the purposes of insurance. An interesting example of a group insurance regime, which was prepared in the spirit of the assumptions outlined above, are the provisions on the insurance contract contained in the new Turkish Commercial Code. Under art. 1496(1) TTK, as a part of one contract, insurance may be established for account of persons belonging to a group of at least 10 people whose members may be identified by the criteria specified by the policyholder. Each person acceding to the group takes advantage of insurance protection until expiry of the group insurance contract (Art. 1496(2) TTK). Any decrease in the number of the persons belonging to the group does not affect validity of the insurance contract (Art. 1496(3) TTK).

In the literature, however, attention is paid to the feature of durability of the connection (relation) between the policyholder and group mem-

${ }^{78}$ Finnish Act on the insurance contract No. 543/1994 of 28 June 1994, Vakuutussopimuslaki 28.6.1994/543, Författningssamling 1450 (accessed: 5.04.2018).

79 Spanish Act on the insurance contract No. 80/2005 of 8 October 2005, Ley 80/2005, de 8 de octubre de Contrato de Seguro, BOE-A-1980-22501. 
bers. One may speak of durability if the existence of a group and the relation to the policyholder are justified by a common purpose (purposes) other than conclusion of the insurance contract. ${ }^{80}$ However, in the context of group insurance, two aspects should be distinguished, namely "cohesion of the group," understood as existence of a common feature specific to all its members, and the group's "durability," manifest in the existence of an extra-insurance connection between the policyholders and members of the group. ${ }^{81}$

As regards normative regimes, it seems desired to introduce a provision which would gear, in group insurance contracts, the emergence of insurance protection to the requirement of meeting the criteria of adherence to the group. ${ }^{82}$ The group adherence criteria rendered in the form of relation to the group organiser should be laid down in the group insurance contract. In the literature, however, there have been indications that, de lege lata, there are no grounds to conclude that the absence of connections between the policyholder and the insured parties undermines the nature of group insurance. ${ }^{83}$

The opinion presented in German and Austrian literature should not go unnoticed. By the concept of group, H. Millauer understands only the multitude of persons, and not the multitude of property interests of a given person. The multitude of persons must be identifiable according to general features, which means that it must be transparent. However, the distinguishing criterion must be personal. ${ }^{84}$ In German doctrine, this is explained by the assumption that a group is composed of persons having certain properties and those properties exist even prior to the conclusion of the group insurance contract. It is indicated that a group created for the sole purpose of concluding an insurance contract may not take advantage of insurance protection under a group insurance contract. ${ }^{85}$

To sum up this part of the investigations, it must be noted that the possibility to apply for insurance protection depends on the fulfilment by the acceding person of the criteria of adherence to the group as specified in the group insurance contract. Furthermore, in the legal systems in which such requirement has been formulated expressly or may be im-

${ }^{80}$ A. Wieser: Gruppenversicherungen. Wien 2006, p. 105.

${ }^{81}$ Otherwise in M. Orlicki: O pojęciu „grupy” w ubezpieczeniach grupowych. „Prawo Asekuracyjne" 2014, No. 1, p. 9.

${ }^{82}$ M. Orlicki: O pojęciu „grupy” w ubezpieczeniach grupowych. „Prawo Asekuracyjne" 2014, No. 1, p. 11.

${ }^{83}$ Further on the subject, see M. Orlicki: O pojęciu „grupy”..., p. 9.

${ }^{84}$ H. Millauer: Rechtsgrundsätze der Gruppenvericherung. Karlsruhe 1966, pp. $17-18$.

${ }^{85}$ F. Herdter: Der Gruppenversicherungsvertrag..., p. 77. 
plied from the essence of the group insurance contract - on the existence of a specific extra-insurance relation between the person applying for insurance protection and the policyholder. These features delimitate the "capacity to be insured," which is vested only in persons who meet the criteria of group adherence. It should be noted at this point that the primary lack of the capacity to be insured may not be identified with a subsequent forfeiture of such capacity, which should be analysed in the context of cessation of protection within the framework of a group insurance contract.

In those systems where the existence of a relation between the policyholder and the insured party is a precondition to affording protection under a group insurance contract, which characteristic of the group may be referred to as its "durability," the absence of such relation will imply primary incapacity to be a member of the group. One should evaluate similarly instances in which, for the lack of certain personal properties, a given person may not be a member of the group of insured parties. A group established in such conditions would not meet the requirement of "cohesion" because the group members would not fulfil the personal criteria of adherence to the group as specified in the group insurance contract.

\section{The question of "open" groups}

In practice, the term "open group" is used to denote group insurance in which the policyholder - agent, broker or another player on the insurance market - is not connected with the persons applying for insurance protection by any extra-insurance relation characteristic of group insurance contracts. It is significant that the term is used in the Polish science of insurance law. ${ }^{86}$ In the same meaning, it is used in the insurance practice in France. The concept of an open group refers to a collectivity of insured parties who are members of an abovementioned ostensible group of insured parties (faux groupe d'assurés). This concept was also used in the annual report of the French Federation of Insurance Companies of 2000. The term "open group" was used to designate a group of the insured parties acting jointly with the intention of being afforded insurance protection. As opposed to group insurance, an "open group" is

${ }^{86}$ Probably as back-reference to market practices, the term is used without much explanation by M. Orlicki: O pojęciu „grupy”..., p. 7. 
formed for the exclusive purpose of common application for the conclusion of individual insurance contracts. ${ }^{87}$ However, between the specific insured persons and the policyholder there subsists no other connection which would allow to conclude a group insurance contract.

Still, it seems that the use of the term "open group" may be confusing and lead to unnecessary misunderstandings or imprecisions.

Conclusion of an insurance contract in the absence of any connection between the persons applying for protection and the policyholder results in the conclusion of several individual contracts. Persons covered by the protection afforded under such contracts would only make up an ostensible group of insured parties (faux groupe d'assurés) and not and "open group." The use of the term "group" in relation to such parties - even if the term is further specified by the adjective "open" - introduces unnecessary terminological confusion, suggesting that insurance protection is afforded under a group insurance contract.

The random circle of persons applying for insurance protection should not be referred to by the term "open group" also because the term "open group," regardless of its denotation, would stand in opposition with a "closed group" (groupe fermé). ${ }^{88}$ Any statement about the "closed" nature of a group may not be made in the context of extra-insurance relations between the policyholder and the insured parties. The closed character of a group relates to the limitation of the possibility of accession to the group insurance by subsequent insured parties. ${ }^{89}$ This expression may be used only in reference to the admissibility of expanding the range of persons who may accede to the insurance. In other words, the narrower the circle of persons who may potentially accede to an insurance contract in light of the terms specified by the policyholder in the agreement concluded with the insurer, the more "closed" a given group. Therefore, it may be assumed that there is a "closed" group, meaning that from the practical point of view, it is impossible to expand its composition. ${ }^{90}$ Its opposite are groups in which it is admissible to modify the composition of members. Only in reference to such groups is it legitimate to use the term "open group." 91

${ }^{87}$ L'assurance française en 2000. Fédération française des sociétés d'assurances, p. 11.

${ }^{88}$ P. Pierre, in: Governance of occupational pensions in Europe: guaranteed security?. Eds. O. Kaufmann, S. Hennion. Heidelberg 2011, p. 96; L. Mayaux, in: Traité de Droit des assurances..., p. 634.

${ }^{89}$ P. Pierre, in: Governance of occupational pensions in Europe..., p. 96.

${ }^{90}$ For example, the policyholder and the insurer may agree that the insurance protection covers persons who, as on a given date, have the status of the policyholder's employee or member of the undertaking organised by the policyholder.

${ }^{91}$ L. Mayaux, in: Traité de Droit des assurances..., p. 650. 


\section{V. "Group" as subject of insurance protection}

The construction of group insurance contracts undoubtedly concentrates on the term "group." In the context of the above considerations, the question must be answered to whom insurance protection is afforded under group insurance contracts. This question has attracted attention of French representatives of the doctrine of insurance law. French authors have noticed the possibility of adopting one of the two following hypotheses. The former assumes that the insured party is a certain collectivity (groupe assuré) enjoying protection within the framework of a group insurance contract. ${ }^{92}$ According to the latter, each person acceding individually to the insurance contract is considered an insured person.

Adoption of the former conception would allow to account for at least two important questions relating to the operation of group insurance. First, such model allows to characterise the operating mechanism of insurance contracts with a variable circle of insured parties. ${ }^{93}$ Essentially, it is adherence to the group that decides about the existence of insurance protection. A person who does not belong to such collectivity may not enjoy insurance protection afforded under a group insurance contract. Second, such position is compatible with the insurance model in which protection emerges automatically and relates to the mere fact of fulfilment of the adherence criteria provided for a group of insured parties. ${ }^{94}$

On the other hand, such perspective, although intellectually stimulating, leads to multiplication of the number of persons involved in an insurance law relationship established under a group insurance contract. Apart from the insurer and the policyholder, one should accept existence of not only the persons being members of the group, who accede to the insurance, but also of the group itself, acting in the role of the insured party. In French law, however, there are no provisions that would permit furnishing such group with legal personality. ${ }^{95}$ Under these circumstances, it would be impossible to assign the insured party (group) with the liability for violating insurance obligations. This conception would practically render meaningless, among others, the provision of Art. L. 113-1(2) CA, which sanctions the cases of damage being caused

${ }^{92}$ Y. Lambert-Faivre, L. Leveneur: Droit des assurances. Paris 2011, pp. 782783.

93 J. Kullmann: Les mécanismes juridiques fondamentaux des assurances collectives. "Revue générale du droit des assurances" 1998, no 3, p. 528.

${ }_{94}$ L. Mayaux, in: Traité de Droit des assurances..., p. 633.

${ }_{95}$ Ibidem. 
by the insured party. ${ }^{96}$ Moreover, violation of the insurance terms by one of the group members would also, out of necessity, be effective against the others. Besides, it is rightly noted in the doctrine that the confinement of the concept of the insured party to a "group" would put into question the "collective" character of those insurance contracts. According to the definition proposed by representatives of French science, a legal act having consequences vis-à-vis persons who have not directly taken part in its performance is referred to as so-called collective legal act (acte juridique collectif). ${ }^{97}$ Recourse to this construction would be unnecessary if the role of the insured party was played by a group and not particular persons acceding to the insurance. Reduction of the group insurance contract to an individual insurance contract does not seem desirable, for example, from the perspective of the protection of interests of particular group members.

Each person acceding the insurance should be considered an insured person, even though risk assessment refers to the group as a whole. ${ }^{98}$ As a result, the number of insured parties is always equal to the number of persons who have effectively acceded to the insurance contract. On the other hand, the concept of group should refer to a certain collectivity enjoying the insurance protection afforded under a group insurance contract. Such group does not have legal personality and in itself is not a subject of rights and obligations under an insurance contract.

\section{Legal construction of the group insurance contract}

In the literature, multiple attempts were made to expound the legal nature of the group insurance contract. Particularly rich in this regard is the legacy of French literature, which may serve as example for the intense development of the science of insurance law. Still, there is no unanimity as to the nature of the legal relationship arising from conclusion of a group insurance contract..$^{99}$ Efforts of the representatives of French literature must be discussed on two levels, on which the doctrinal discussion was conducted.

96 Ibidem.

97 A.L. Pastre-Boyer: L'acte juridique collectif en droit privé français. Aix-enProvence 2006, p. 231.

98 Cf. E. Stroiński: Ubezpieczenia na życie. Teoria i praktyka. Warszawa 2003, p. 284.

${ }^{99}$ M. Bigot-Gonçalves: Les assurances..., p. 75. 
The researches on the first level attempt to answer the question if, in the context of group insurance, one or more contracts are concluded. According to the historically older conception, referred to as "unitarian," the existence of only one agreement is sufficient for the emergence of protection, that is, the agreement between the insurer and the group organiser (policyholder). ${ }^{100}$ On the other hand, the second position (conception "éclatée"), adhered to by the vast majority of contemporary authors, is based on the assumption that apart from the contract between the insurer and the group organiser there are simultaneously as many separate insurance contracts as there are insured parties. ${ }^{101}$ For the purpose of this study, this view will be referred to as the conception of "dispersed" insurance relationship.

It is, however, only one of the two abovementioned levels of dispute on the juridical nature of the group insurance contract. It may not be analysed in isolation from the question about the legal character of the relationships arising under a group insurance contract. The legislator does not decide expressly in respect of the construction under which it is possible to afford insurance protection to group members. In the doctrine, many proposals were formulated which were to account in a comprehensive way for the nature of that contract. Most attention, however, was paid to three of them. The first proposal was based on the belief that the policyholder acts on behalf of the parties insured within a group on the negotiorum gestio (gestion d'affaires) basis. ${ }^{102}$ The second proposal was that the group insurance contract is, in fact, an insurance for account of another (assurance pour compte). ${ }^{103}$ Proponents of the third proposal pointed out that in consequence of concluding the insurance contract the insurer itself makes a promise to enter into insurance contracts with interested parties (promesse d'assurance).$^{104}$ None of the above proposals has been met with universal acceptance. In the doctrine, it did not go unnoticed that although the specific conceptions allow to account for certain mechanisms characteristic of group insurance contracts, none of them convincingly expounds all the aspects of the construction. ${ }^{105}$ The influence on the shape of the contemporary discussion of the status of

${ }^{100}$ C. Goldie-Genicon: L'assurance de groupe à l'épreuve de la législation sur les clauses abusives. "RD” 2008, p. 2448; L. Mayaux, in: Traité de Droit des assurances..., pp. $655-656$.

${ }^{101}$ L. Mayaux, note sous Cass. civ. 1re, 16 janvier 2001, Revue générale du droit des assurances 2001, p. 347 i n.; L. Mayaux, in: Traité de Droit des assurances..., pp. $661-664$.

${ }^{102}$ M. Bigot-Gonçalves: Les assurances..., pp. 82-85.

${ }^{103}$ M. Pauffin de Saint Morel: L'assurance de groupe. Paris 1977, p. 67.

104 M. Bigot-Gonçalves: Les assurances..., pp. 80-81.

${ }^{105}$ Ibidem, pp. $75 \mathrm{ff}$. and the literature cited therein. 
group insurance was, however, exerted by the second and the third of the abovementioned conceptions. While the second one (group insurance contract as insurance for account of another) inspired, in the first place, proponents of the unitarian theory, the third of the proposed models was developed by representatives of the conception of the dispersed insurance relationship.

\section{Unitarian conception and group insurance}

In the light of the assumptions of the unitarian conception, for the emergence of insurance protection of the insured parties it is sufficient that a contract is concluded between the group organiser and the insurer. It seems a truism to state that the insured parties are not the parties to that contract. In effect, there arises a question about the basis on which they gain the right to claim performance by the insurer in case of occurrence of an insurance accident. Proponents of the said conception refer in this regard either to the mechanism at play within the framework of insurance contracts for account of a third party (assurance pour compte $)^{106}$ or to a broader category of contractual provisions under which performance is stipulated for the benefit of a third party (stipulation pour autrui). ${ }^{107}$ Certain authors seek elements of both these constructions in group insurance contracts. ${ }^{108}$

In older French literature, it was indicated that group insurance contracts bear certain similarities with the contract for account of another. ${ }^{109}$ Certain authors even consider group insurance as one of the types of insurance contract for account of another. ${ }^{110}$ In the period preceding

${ }^{106}$ For more on the construction of insurance for account of another (assurance pour compte), see P.S. Boulay-Paty: Traité des Assurances et des Contrats à la Grosse D’Émérigon, vol. 1. Paris 1827, pp. 326-332; L. Mayaux: La nature juridique de l'assurance collective. In: Les grandes questions du droit des assurances. Ed. L. Mayaux. Paris 2011, p. 60.

107 J. Barthélemy: Évolution du droit social: une tendance à la contractualisation mais un rôle accru des droits fondamentaux du travailleur. Paris 2009, p. 356.

108 J.M. Binon: Réflexions autour de quelques développements jurisprudentiels récents dans les assurances maladie et accidents. In: Liber Amicorum René Van Gompel. Ed. J. Rogge. Diegem 1998, pp. 17-22.

${ }_{109}$ M. Bigot-Gonçalves: Les assurances..., pp. 76-80.

${ }^{110}$ H. Montcharmont: L'assurance pour compte en matière terrestre. Paris 1931, p. 8; P.G. Marly: Droit..., p. 58. 
the entry into force of the Act of 31 December $1989,{ }^{111}$ it was the dominant conception in French literature, which was to serve to explain the legal nature of group insurance. ${ }^{112}$ This thought seems also leading in the Polish science of insurance law. The position which should be considered dominant in the doctrine is that the principal construction on whose basis the legal regime of group insurance is developed is the insurance contract for account of another. Therefore, the group insurance contract is an insurance agreement concluded by the policyholder in his own name and for account of a number of third parties. ${ }^{113}$

It must be emphasised that the construction of insurance contract for account of another, as provided for in French law, may not be fully identified with the solutions provided for in other legislative regimes.

For the sake of systematisation of the investigations, it should be recalled that, for instance, in Polish law the insurance contract for the benefit of a third party is present in two forms: as insurance contract for the benefit of a third party sensu stricto and as insurance contract for account of another (Art. $808 \mathrm{CC}$ ). It must be noted that the insurance contract for account of another is a qualified insurance contract for the benefit of a third party.

The insurance contract for the benefit of another sensu stricto consists in that the policyholder is at the same time the insured party, which means that the protection covers his property interest and it is the policyholder that is obliged to pay insurance premium. The policyholder seeks to protect his own property interest or his own life and, at the same time, designates a person entitled to receive the insurance benefit in case of occurrence of the accident envisaged in the contract, wherein such person does not have to be indicated by name. It is sufficient that it is possible to identify the entitled party, and in life insurance contracts such person may even be the bearer of the policy. On the one hand, the third party is entitled to the benefit paid by the insurer in the event of occurrence of the insurance accident. In such situations, the third party is referred to as the beneficiary. On the other hand, the insurance contract for account of another is the case when the policyholder insures a third party's property or non-property interest but acts in his own

${ }^{111}$ Act No. 89-1014 of 31 December 1989 adjusting the Insurance Code to the opening of the European market (Loi n 89-1014 du 31 décembre 1989 portant adaptation du code des assurances à l'ouverture du marché européen, JO nº 2 du 3.01.1990).

${ }_{112}$ M. Pauffin de Saint Morel: L'assurance de groupe. Paris 1977, p. 67; see Y. Lambert-Faivre, L. Leveneur: Droit des assurances. Paris 2011, p. 195.

${ }^{113}$ See B. Kęszycka: O potrzebie uwzględnienia specyfiki ubezpieczeń grupowych na życie w kodyfikacji prawa ubezpieczeniowego. In: O potrzebie polskiego kodeksu ubezpieczeń. Ed. E. Kowalewski. Toruń 2009, p. 238. 
name, which means that one person is the policyholder and another is the person in whose property interest the insurance is concluded. ${ }^{114}$

The German Act on the insurance contract covers the insurance for account of another (Versicherung für fremde Rechnung) in Section II on property insurance, devoting to that institution the provisions of $\S 43-48$ VVG. Insurance for account of another is defined as insurance contract concluded by one person in his or her own name for account of another person, who may but does not have to be designated by name (§43 VVG). On the other hand, § 150 VVG provides that life insurance may have as its subject the life of the policyholder or another individual. Similarly, Art. 808 of the Polish CC reads that the policyholder may conclude an insurance contract for account of another. This provision has been placed among general provisions on the insurance contract, which means that it applies both in case of concluding property and personal insurance contracts.

In the definitions cited above, the element that comes to the fore is the specific subjective structure of the insurance contract for account of another. The essence of that insurance is multitude of subjects (but not multitude of the contractual parties since the contractual parties are solely the insurer and the policyholder). The policyholder concludes with the insurer a contract for account of the insured party if the insured party has interest in obtaining the insurance protection. In Polish legislation, there are no specific provisions amounting to the legal regime of group insurance. The juridical construction of group insurance is multiplied based on the contract of insurance for account of another.

Under Art. L. 112-1(1) CA, an insurance contract may be concluded for account of a designated person (pour le compte d'une personne déterminée) through an attorney acting under a general or specific power of attorney or even without authorisation. Contrary to the literal meaning of this provision, Art. L. 112-1(1) CA does not cover contracts concluded "for account" or even "for the benefit" of a third party in the understanding attached to these concepts by the literature. The provision of Art. L. 112-1(1) CA confirms only the rule adopted under the French Civil Code that a legal act may be performed through an attorney. ${ }^{115} \mathrm{An}$ agreement concluded on the terms set out in Art. L. 112-1 CA is therefore binding on the represented party. The intermediary (attorney, person managing the insured party's interests or even falsus procurator), when concluding the insurance contract, acts in the name of the repre-

${ }^{114}$ See judgment of the Supreme Court of 25 January 2000, I CKN 331/98, LEX No. 56807.

${ }^{115}$ L. Grynbaum (ed.): Assurances 2013-2014. Acteurs, contrat, risques des consommateurs, risques des entreprises. Paris 2012, p. 335. 
sented party, who becomes obliged thereunder to pay premium to the insurer. ${ }^{116}$ This is not a construction that would suffice to account for the mechanism of the group insurance contract. The role of the policyholder in the group insurance contract is not limited merely to making the declarations of intent on behalf of acceding parties.

From the point of view of the present investigations, a far more interesting construction is specified in Art. L. 112-1(2) CA. The provision of Art. L. 112-1(2) CA envisages the possibility to conclude an insurance contract for account of a person unspecified at the time of making the contract but referred to by mere indication of circumstances in which the insurer's obligation to pay the benefit may materialise (pour le compte de qui il appartiendra). In effect, the legislator indicates what consequences attach to the conclusion of a contract based on such construction. The use in the contract of the clause under Art. L. 112-1(2) CA must be considered as conclusion of the contract in the interest of the policyholder with simultaneous stipulation of a benefit for a third party. The construction described in that provision is deemed to be the so-called proper insurance contract for account of another. ${ }^{117}$

The German practice of insurance has also developed a conception of insurance for the benefit of the one whom the insurance concerns (Ger. Versicherung für Rechnung "wen es angeht"). ${ }^{118}$ The insured party is identified at the time of occurrence of the insurance accident, however, at the latest at the time of payment of the cash benefit by the insurer. ${ }^{119}$

The $\mathrm{BGH}^{120}$ has described the relationship between the policyholder and the co-insured - that is, division between material and formal "ownership" - as a fiduciary relationship (Treuhandverhaeltnis) once the insured event has occurred. Where due to the policyholder's noncompliance with duties to be observed after the insured event occurred the co-insured's right to the benefit is negatively affected, the co-insured

${ }^{116}$ Cass. 1ère civ., 18 juill. 1962: Bull. civ. I, no 386; Revue générale des assurances terrestres 1962, p. 488, note A. Besson; Cass. 1ère civ., 14 janv. 1959: Bull. civ. I, no 386; Revue générale des assurances terrestres 1959, p. 328.

117 J. Bigot, in: Traité de Droit des assurances. Tome 3. Le contrat d'assurance. Ed. J. Bigot. Paris 2002, p. 103.

${ }^{118}$ Cf. W. Mogilski: Umowa ubezpieczenia na rzecz osoby trzeciej. In: Ubezpieczenia $w$ gospodarce rynkowej, Vol. 1. A. Wąsiewicz. Bydgoszcz 1994, p. 90 and the literature cited therein.

${ }^{119}$ In German law, this juridical construction was regulated expressly in $\S 48$ VVG, by stating that if the insurance is concluded for account of "the one whom it may concern" or if it does not follow from the contract whether the contract was concluded on account of the policyholder or another party, § 43-47 VVG will apply as long as the circumstances indicate that the interest to be insured is the one of another party.

${ }^{120}$ Bundesgerichtshof. 
is entitled to claim damages from the policyholder for the breach of the fiduciary relationship. ${ }^{121}$

Such construction is also admissible in Polish law under the first sentence of Art. $808 \S 1 \mathrm{CC}$, according to which the insured party does not have to be designated by name in the contract unless this is necessary for the specification of the object of the insurance. This means that if the insured party can be identified by the object of insurance, he does not have to be indicated by name in the contract. ${ }^{122}$ If the insured party's name does not appear in the contract, he is entitled to the insurer's benefit if he can provide the insurance document to the insurer and prove his right to the object of the property insurance or to the sum under the personal policy insurance.

The difficulties relating to the specification of the nature of the socalled proper insurance contract for account of another follow from the subsistence in such cases of an interest in the conclusion of the contract both on the part of the policyholder and the insured party. ${ }^{123}$ The insurance contract concluded according to the provision of Art. L. 1121(2) CA in certain circumstances may at the same time be a contract insuring property and a civil liability contract. ${ }^{124}$ This position was met with acceptance of the doctrine despite numerous controversies relating to the construction provided for by the legislator in Art. L. 112-1(2) CA. ${ }^{125}$ The policyholder, being the owner of the assets which he entrusts to another entrepreneur for storage, by concluding the insurance contract under Art. L. 112-1(2) CA for account of the storekeeper, on the one hand, insures his property interest, and on the other, concludes that entrepreneur's civil liability insurance. This solution is more profitable to the parties than conclusion of a contract for the insurance of the assets by their owner. The latter would receive the benefit in case of damage of the assets entrusted for storage, which, however, would open the way for the insurer to assert recourse claim against the storekeeper. In turn, this would lead to an increase of the price for the service provided by the storekeeper. At the same time, also a solution consisting in the conclusion of a civil liability insurance by the storekeeper would not be

${ }^{121}$ See: R. Koch: Insurance Law in Germany. Wolters Kluwer 2018, p. 138.

${ }^{122}$ Cf. A.M. Kubiak: Umowa ubezpieczenia ubezpieczenia na rzecz osoby trzeciej i na cudzy rachunek. Bydgoszcz-Poznań 2008, p. 65.

${ }^{123}$ M. Picard, A. Besson: Les Assurances terrestres en droit français. Le contrat d'assurance, vol. 1. Paris 1975, p. 430.

${ }^{124}$ See Cass. 1ère civ., 5 février 1974, JCP 1974 II.17893.

${ }^{125}$ An analogous example relating to an insurance contract concluded by a carrier is discussed in more detail in L. Grynbaum (ed.): Assurances 2013—2014..., pp. 335— 336. 
satisfactory. The owner of the assets would not receive compensation if the storekeeper could invoke exonerating circumstances excluding the storekeeper's liability to the injured party.

As a part of considerations on the formula of group insurance, it is indicated that, as with regard to the insurance contract under Art. L. 112-1(2) CA, the group organiser may be interested in the conclusion of an insurance contract for account of the insured parties. The policyholder's interest in the emergence of insurance protection may follow from the obligations incurred against employees. ${ }^{126}$ In case of group i surance contracts of borrowers, it is the group organiser (lender) that secures itself against the counterparty's insolvency. ${ }^{127}$ A sports association concluding a group insurance contract in connection with an organised event also acts with the intention to secure itself against possible claims of its participants. It is much less probable that a claim for compensation is asserted against the organiser of a given event by its participant when such participant receives pension or other benefit from the insurer. ${ }^{128}$

However, there are essential differences between the constructions of group insurance contract and insurance contract for account of another. In the French context, they eventually led to the pursuit of other juridical solutions which were to account for the group model of granting insurance protection.

First, as opposed to the said understanding of the insurance contract for account of another, in group insurance the policyholder does not necessarily have to be, at the same time, an insured party. ${ }^{129}$ The insurance risk does not have to refer to such policyholder. While in the insurance contract under Art. L. 112-1(2) CA the policyholder must always be interested in the conclusion of the contract, such interest is not a necessary condition for the conclusion of a group insurance contract.

Second, in the context of the construction under Art. L. 112-1(2) CA, specification of the insured party takes place upon the materialisation of risk defined in the contract. Coming back to the example presented above, at the time of concluding the insurance contract, the policyholder is not obliged to designate the storekeeper by name. The policyholder agrees to the insurance protection being afforded to any entity to whom

${ }^{126}$ P. Demay de Goustine: Les problèmes juridiques de l'assurance de groupe. Paris 1977, p. 101.

${ }^{127}$ G. Courtieu: Assurance des emprunteurs. Garanties collectives et situationes personnelles. Responsabilité civile et assurance 2009, no 3, p. 45.

${ }_{128}$ V. Nicolas: Essai d'une nouvelle analyse du contrat d'assurance. Paris 1996, p. 209.

${ }^{129}$ P. Demay de Goustine: Les problèmes..., p. 105. 
the policyholder entrusts custody of its specific assets. In the group insurance contract, the status of the insured party is obtained as on accession by a group member to the insurance contract. ${ }^{130}$ This thought is also present in Polish literature of the subject. Within the framework of group insurance, the circumstance is crucial that at the time of the contract's conclusion the policyholder does not know all persons who may be covered by the insurance protection since they are individually identified at a later time.

Third, in the insurance contract for account of another, the risk is known at the time of concluding the contract both in its qualitative and quantitative dimension. At the stage of concluding the contract, the parties mutually agree that the insurance protection is going to cover specific risks and one insured party even though the insured party as such is not yet specified. On the one hand, in the example presented above, the policyholder incurs risk relating to the civil liability of any but only one storekeeper. On the other hand, certain authors point out that in group insurance contracts the risk which the insurer undertakes to incur depends on the circle of persons who have effectively acceded the insurance. At the stage of the contract being concluded by the insurer and the policyholder, the number of persons who will eventually enjoy the insurance protection is still unknown. According to certain representatives of the legal science, only in the case of insurance contracts accession to which is compulsory can one speak of the knowledge of risk at the time of concluding the contract. ${ }^{131}$ It seems, however, that this position is not convincing. In insurance contracts with compulsory accession, the range of acceding parties may also change. Only with regard to such insurance contracts in which the parties have excluded the possibility of changing group's personal composition may one speak about the knowledge of risk already at the time of concluding the contract. Yet, it is still possible that a member of the group loses the properties which allowed to cover him with the insurance protection.

Fourth, a further obstacle in the application of the construction of proper contract for account of another are doubts as to the admissibility of its use for the purposes of concluding personal insurance contracts. ${ }^{132}$ For example, the French legislator provided for special provisions on the conclusion of personal insurance contracts for account of another (assurance sur la tête d'autrui). ${ }^{133}$

${ }^{130}$ E. Roueil: Essai sur le contrat d'assurance collective. Orléan 1998, p. 127.

${ }^{131}$ M. Bigot-Gonçalves: Les assurances..., p. 77.

${ }^{132}$ L. Grynbaum (ed.), Assurances 2013-2014..., pp. 335-336.

${ }^{133}$ See Art. 132-2 CA. 
The abovementioned doubts have finally led to the contestation in French science of the belief in the possibility to recognise the group insurance contract as one of the types of insurance contract for account of another. ${ }^{134}$ This does not mean, however, that the efforts of the researchers were fruitless. The doctrinal discussion triggered by the belief in the admissibility of classifying the group insurance contract as contract for account of another allowed to draw attention to the differences between insurance contracts in which accession is compulsory and ones in which accession is left to the discretion of an interested party, which is going to be discussed in a further part of this study.

As a part of further investigations of the legal nature of collective insurance contracts in French science, the construction of stipulation of benefit for a third party (stipulation pour autrui) was invoked. ${ }^{135}$ However, this view, for a relatively long period of time, competed with the judicial position based on the belief that the insurance contract is a sui generis construction and any similarities to the stipulation of benefit for a third party are only ostensible. ${ }^{136}$ An analogous opinion is formulated in the Polish literature to account for the relationship between Art. 393 CC and Art. 808 CC. It is generally accepted that insurance for the account of another is an independent institution of insurance law. The provision of Art. $808 \mathrm{CC}$ is lex specialis in relation to Art. $393 \mathrm{CC}$ - Art. $808 \mathrm{CC}$ covers all questions regulated in Art. $393 \mathrm{CC}$ but renders some of them differently, wherein it exceeds the scope of the general provision. ${ }^{137}$

The admissibility to apply the construction of benefit for a third party is decided in French law by Art. 1165 CC. ${ }^{138}$ Under this provision, "contracts are binding only on the contracting parties; they may however have a favorable or unfavorable consequence for third parties in situations set forth in Art. 1121" CC. The cited Art. 1121 CC provides for the admissibility of stipulating a benefit for a third party "when it conditions performance to the stipulating party or constitutes a donation" to another person. ${ }^{139}$ The stipulating party, however, may not revoke the stipula-

${ }^{134}$ M. Bigot-Gonçalves: Les assurances..., p. 80.

135 V. Nicolas: Essai..., pp. $206 \mathrm{ff}$.

${ }^{136}$ See F. Ber dot: L'assurance de groupe après les réformes législatives du 31 décembre 1989. "Revue générale des assurances terrestres" 1990, p. 775; J. Landel: Les mécanismes juridiques de l'assurance de groupe. Ass. Fr. 1983, p. 76 and the case-law cited therein.

${ }_{137}$ See B. Kucharski: Przeniesienie praw z umowy ubezpieczenia. Warszawa 2010, p. 178; W. Warkałło, in: System prawa cywilnego. Prawo zobowiazań - część szczegótowa, vol. 3, part 2. Ed. S. Grzybowski. Ossolineum 1976, p. 925.

${ }^{138}$ C. Alter, S. Bar: Les effects du contrat. Waterloo 2000, p. 36.

${ }^{139}$ More in A. von Mehren: The Code and Comparative Analysis of Formation and Form. In: The Code Napoleon and the Common-Law World. Ed. B. Schwartz. New Jersey 1998, p. 129. 
tion if the third party declared the intention to take advantage of such stipulation. Within the subjective framework characteristic of the group insurance contract, the group organiser (policyholder) plays the role of the stipulating party, the insurer - of the promising party, and the beneficiaries of the benefit are the parties insured within a group or persons designated by such insured parties.

Nonetheless, acceptance of this construction does not remove all doubts relating to the legal position of the insured party. Just as in Polish literature, ${ }^{140}$ the question of admissibility of imposing the obligation to pay the premium on a person from outside the contractual relationship remains disputable. Assuming that the insured party is not a contractual party, it must be concluded that the obligation to pay premium may be imposed exclusively on the policyholder. This is the case because only the policyholder may incur specific obligations against the insurer.

In the French judicial practice, however, a controversial solution was adopted consisting in reconciliation of the stipulation of benefit for a third party (stipulation pour autrui) with the insured party's obligation to pay premium to the insurer. The judgment of the Cassation Court of 8 December 1987 paved the way for the case-law according to which certain obligations under the contract may be imposed on a third party if they are expressly accepted by such third party. ${ }^{141}$

However, the basic objection that may be formulated against the views depicted above is the dogmatic attempt to follow the assumptions of the unitarian conception. ${ }^{142}$ This model accounts only for group insurance in which the group organiser performs the role of an insured party. Moreover, the said conception does not give a convincing and universal answer to the question about the admissibility to impose specific obligations on the acceding party. Assuming that the insured party, at least impliedly, consents to being imposed with certain obligations, it must be considered if such consent does not give rise to an obligation to pay the premium independently of the insurance contract concluded by the policyholder. These remarks necessitate outlining the assumptions of the conception of "dispersed" insurance relationship, based on the conviction that the insurance contract sensu stricto holds between the group members and the policyholder.

${ }_{140}$ M.P. Ziemiak: Strony i podmioty stosunku grupowego ubezpieczenia na $\dot{z} y c i e$. In: Ubezpieczenia grupowe na życie a prawo zamówień publicznych. Ed. E. Kowalewski. Toruń 2011, pp. 115-116.

${ }^{141}$ Cass. 1ère civ., 8 déc. 1987, Bull. civ. I, no 343.

${ }^{142}$ Cf. J. Ghestin, C. Jamin, M. Billiau: Traité de droit civil, Les effets du contrat, 3e éd. Paris 2001, p. 1050; C. Larroumet: Les obligations, Le contrat, 2e partie, Effets, 6e éd. Paris 2007, p. 982. 


\section{Conception of dispersed insurance relationship and group insurance}

Under the assumptions of the second position, referred to in the present study as the conception of dispersed insurance relationship, each member of the group is a party to a separate contract between such member and the policyholder. Making a declaration of accession to the insurance by a person applying for insurance protection is deemed, by proponents of this conception, as placement of an offer. On the other hand, the policyholder, by confirming acceptance of the declaration, makes a declaration of the offer's acceptance. ${ }^{143}$ It also cannot be excluded that silence of the insurer will be interpreted as consent to the insurance protection being granted.

Certain representatives of the French doctrine look for an argument in favour of such view in Art. L. 141-6 CA. Under this provision, in the group insurance contracts specified in Art. L. 141-1 CA ${ }^{144}$ and in contracts financed by premium capitalisation bearing features of the contracts under Art. L. 141-1 CA, the policyholder is considered to be the insurer's representative in relation to the acceding party, the insured party or the beneficiary, to the exclusion, however, of such acts of which the acceding party was notified in advance. ${ }^{145}$ Proponents of this opinion indicate that the policyholder is only the insurer's attorney in relation to the insured parties, and so the proper insurance relationship is the one between the insurer itself and a group member. ${ }^{146}$

However, formulation of any categorical conclusions on the model of insurance protection within the framework of group insurance under the norm of Art. L. 141-6 CA seems illegitimate. This provision introduces two essential restrictions of the policyholder's authorisation to act on behalf of the insurer. First, under Art. L. 141-6 CA, it does not substitute a grant of the power of attorney with the consequences of such legal act being made by the represented party's declaration of intent. The policyholder is merely "deemed" to be the insurer's representative, and only in

${ }^{143}$ L. Mayaux, in: Traité de Droit des assurances. Tome 4..., p. 660.

${ }_{144}$ To the exclusion of those regulated under the Act No. 89-1009 of 31 December 1989 reinforcing the safeguards of persons insured against certain types of risk, referred to as loi Evin (La loi n 89-1009 du 31 décembre 1989 renforçant les garanties offertes aux personnes assurées contre certains risques, JO du 2 janvier 1990).

${ }_{145}$ The amendments of that provision are presented mode widely in Y. Lambert-

-Faivre, L. Leveneur: Droit des assurances. Paris 2011, pp. 784-785.

${ }^{146}$ C. Goldie-Genicon: L'assurance de groupe..., p. 2450. 
relation to a limited circle of persons (acceding party, insured party or beneficiary). Second, the scope of such authorisation has been objectively limited. The policyholder substitutes the insurer exclusively in acts relating to the accession of subsequent interested parties and performance of the contract itself. This provision should not be interpreted extensively. It is rightly noticed in the doctrine that drawing too far-reaching conclusions from Art. L. 141-6 CA would lead to a situation in which the policyholder is treated at the same time as the person concluding the contract with the insurer (arg. ex Art. L. 141-1 CA) and the person representing the same insurer (Art. L. 141-6 CA). ${ }^{147}$ It seems, however, that introduction of the provision of Art. L. 141-6 CA was dictated not as much by the intention to expound the mechanism under which insurance protection is afforded under the group insurance contract as by the need to ensure to the acceding parties a direct contact with the insurer's representative. One should not forget that group insurance, from the perspective of insured parties, is to make a simplified mechanism of obtaining insurance protection.

This problem was identified also in German literature in the context of the distinction between improper group insurance (unechte Gruppenversicherung) and proper group insurance (echte Gruppenversicherung). ${ }^{148}$

As opposed to proper group insurance, improper group insurance is composed not of a uniform insurance contract but a number of individual contracts which are combined on account of the uniformity of insurance coverage. In German literature, it is emphasised that the improper group insurance contract is a model applicable to life insurance only. Joint performance of the contract and activities of the group organiser acting upon authorisation of individual group members are characteristic features of the discussed category of group insurance. It is pointed out that the contract is not concluded directly and separately by individual persons but by the group organiser as the authorised attorney. Nonetheless, the position of the group organiser is not exclusively limited to the role of representative. The group organiser assumes his own contractual obligations, such as the obligation to handle all matters vis-à-vis group members on one hand, and the insurer on the other. The power of attorney granted to such organiser by the group members authorises the organiser not only to conclude the insurance contract but also to make and receive any declarations pertaining to insurance relationships, including termination of

${ }^{147}$ V. Bourdon: La distribution de l'assurance par les associations, contribution à l'étude des assurances collectives. Paris 2002, p. 184.

148 This terminology was coined by H. Millauer: Rechtsgrundsätze der Gruppenvericherung, Karlsruhe 1966, pp. 107 et seq. 
the contract or demanding payment of the insurance benefit. ${ }^{149}$ In Polish literature, similar position is taken in reference to group life insurance. For instance, it is indicated that an employer, while concluding life insurance with an insurer, may not incur obligations whose debtors would be the insured employees. For that purpose, the employer would have to be duly authorised by the insured parties. If so, according to the authors, such employer, when concluding the insurance contract with the insurer, may act only upon authorisation of the interested parties, that is on their behalf, as an attorney. A proof of such view, according to the scholars, is the requirement that each insured party should submit a so-called declaration of accession. Without such declaration from a person interested in insurance protection in the framework of life insurance, the protection in respect of such person may not arise at all (Art. $829 \S 2$ CC). ${ }^{150}$

The model of dispersed insurance relationship is compatible with the opinion that the contract between the insurer and group organiser is only an agreement organising future insurance relationships (framework agreement). The function of such framework agreement is exhausted by the specification of the amount of insurance premium and the "technical" aspect of concluding proper insurance contracts. It does not include the essential elements of the insurance contract. The insurer does not undertake thereunder to pay the benefit in case of occurrence of the risk stipulated in the contract or, at least directly, to afford insurance protection to a specific person.

As opposed to a typical framework agreement, under which further implementing contracts are concluded between the same parties, the group insurance contract is concluded by persons other than the parties to the implementing (derivative) contracts. On the one hand, the contract organising the insurance holds between the insurance operator and the insurer. On the other hand, the implementing contracts are concluded between the insurer and members of the group of insured parties. A different catalogue of persons entering into particular contracts does not deprive the contract concluded between the organiser and the insurer of the character of framework agreement. ${ }^{151}$ On the basis of such observations, it may be concluded that the use of the term "insured party" as such in reference to a party of the framework agreement may raise objections. The role of such entity is more accurately rendered by the terms "group organiser" or "insurance operator."

${ }^{149}$ A. Wieser: Gruppenversicherungen..., pp. 112-113.

${ }^{150}$ E. Kowalewski, M. Wałachowska: Nieadekwatność prawa zamówień publicznych do grupowych ubezpieczeń na życie - potrzeba nowych uregulowań prawnych. "Wiadomości Ubezpieczeniowe" 2010, No. 3, pp. 35-36.

151 J.M. Mousseron: Technique contractuelle. Paris 1999, p. 87. 
In German literature it is also indicated that the abovementioned "improper group insurance" contract is a framework agreement outlining the course of action for the conclusion of the insurance contract as well as organisational and economic boundary conditions of the insurance. In the same way, it forms a basis for the establishment of a multitude of individual insurance relationships which, for the sake of their joint realisation and administration, have been mutually connected. ${ }^{152}$ It is argued that by the term "framework agreement" one should understand a contract between the insurer and the so-called framework agreement partner (Rahmenvertragspartner) which covers framework provisions and guidelines for the conclusion of individual insurance contracts with group members but in itself does not give rise to an obligational relationship. ${ }^{153}$ The individual insured members of the group are at the same time individual and independent policyholders.

A further consequence of accepting the conception outlined above is the conclusion that the framework agreement is not an insurance agreement sensu stricto. Therefore, it is not subject to the substantive law provisions relevant to the assessment of rights and obligations of the parties to direct insurance contracts. Realising the threats following from such essential limitation of the scope of application of insurance law, certain French authors opt for approaching the organisational agreement as framework insurance agreement (contrat cadre d'assurance), ${ }^{154}$ which is to permit coverage of such agreement by the scope of application of insurance law. A framework agreement organising the insurance contract remains an innominate contract. ${ }^{155}$ Its inconclusive nature gives rise to interpretive doubts. It has no separate normative regime. In effect, one should always answer the question if, for the assessment of a given situation, the applicable rule is a provision of insurance law or rather general provisions of the law of obligations.

It is significant that the French judiciary dissociates itself from the doctrinal investigations relating to the "unitarian" conception and the conception of "dispersed" insurance relationship. ${ }^{156}$ The majority of older court decisions include predominantly references to the former position. Attention of the judiciary was primarily focused on consequences of the stipulation of benefit for a third party in the spirit of the unitar-

${ }^{152}$ So writes R. Magnusson: Gruppenversicherung, insbesondere in der Lebensversicherung in Möller, Winter, Materialien des zweiten Weltkongresses für Versicherungsrecht der internationalen Vereinigung für Versicherungsrecht, Band 5. Karslruhe 1967, p. 113.

${ }_{153}$ A. Wieser : Gruppenversicherungen..., p. 110.

154 G. Sargos : Le contrat d'assurance..., p. 22.

${ }_{155}$ M. Bigot-Gonçalves: Les assurances..., p. 108.

156 C. Goldie-Genicon: L'assurance..., p. 2450. 
ian conception. ${ }^{157}$ In newer case-law, more attention is paid to the existence of an obligational connection between the group members and the policyholder, ${ }^{158}$ which is characteristic of the conception of dispersed obligational relationship.

The source of additional doubts are relatively ambiguous conclusions of the French judiciary. Yet in 1986, the Court of Cassation, in its Rapport Annuel, presented an opinion that "without any doubt, the group insurance contract is based on the construction of "stipulation of benefit for a third party", under which the promising party (insurer) undertakes to the policyholder to propose insurance on the terms mutually agreed by both these entities to the acceding parties." ${ }^{159}$ However, the Court of Cassation did not develop that thought. In particular, it did not explain what the insurer's obligation to "propose insurance" consists in. Further, it did not specify if the acceptance of the insurer's offer leads to conclusion of a separate insurance contract, which would correspond to the assumptions of the conception of dispersed obligational relationship, or if the said "proposition" of insurance consists in obtaining the insured party's consent to the conclusion of insurance for account of such insured party.

Profound analysis of the French case-law to date allows to identify also more unambiguous statements. In the judgments of the Court of Cassation of 9 March $1983^{160}$ and 22 May 2008, ${ }^{161}$ the Court recognised in group insurance contracts elements of both benefit for a third party and mutual obligation between the insurer and the acceding party. ${ }^{162}$

In the judgment of 9 March1983, ${ }^{163}$ an opinion was voiced that stipulation made for the benefit of a third party may lead to the interested party being given a possibility to conclude a separate contract with the promising party. In the considerations made in that case, it was mentioned that the request made by the interested party to become covered by the insurance protection should be treated as an offer addressed to the insurer for the conclusion of a contract. ${ }^{164}$

${ }^{157}$ Cass. 1ère civ., 4 nov. 1992, Revue générale des assurances terrestres 1992.836, Cass 1ère civ., 26 mai 1993, Resp. civ. et assur., 1993; Cass. 1ère civ., 9 mai 1996, Revue générale du droit des assurances 1996.615; Civ. 1ère, 5 déc. 1978, D. 1979. Jur. 401.

${ }_{158}$ See C. Goldie-Genicon: L'assurance..., p. 2450 and the case-law cited therein.

159 Rapport annuel de la Cour de cassation. Paris 1986, p. 198; Rapport Annuel 2009. Les personnes vulnérables dans la jurisprudence de la Cour de cassation. Paris 2009 , p. 167.

160 Cass. 1ère civ., 9 mars 1983, Revue générale des assurances terrestres 1983. 526.

${ }^{161}$ Cass. 1ère civ., 22 mai 2008, D. 2008. Jur. 1954, note D.R. Martin; JCP G 2008.

II. 10133.

162 G. Sargos: Le contrat d'assurance..., p. 21.

${ }^{163}$ Cass. 1ère civ., 9 mars 1983, Revue générale des assurances terrestres 1983. 526.

164 Ibidem. 
In turn, the situation that led to the delivery of the judgment of 22 May $2008^{165}$ was that a borrower acceded to a collective insurance agreement concluded by a bank for the purpose of securing repayment of the granted credits. In the insurance contract itself, a provision was included under which the insurer had the right to refuse to pay the benefit. Upon ascertaining that the insured party was unable to work and upon his acquisition of pension rights, the borrower demanded that the insurer should repay his liabilities to the bank. In the dispute before the court, the borrower invoked abusive nature of the clause included in the contract under which the insurer's liability was excluded. The court of I instance dismissed the suit in its entirety. The judgment was upheld by the decision of the court of II instance, which concluded that in the examined case the protective regime under Art. L. 132-1 of the Consumer Code could not apply. ${ }^{166}$ The disputable clause was included in a contract between the insurer and the bank, and that contract was not covered by the Code's scope of application.

The essence of the case then referred to resolution by the Court of Cassation boiled down to answering the question whether accession to a group insurance contract, as a consequence of a benefit being stipulated for a third party, gives rise to the emergence of a bilateral contractual relationship between the insured party and the insurer, which would be subject to the provisions of Art. L. 132-1 of the Consumer Code.

Finally, the Court of Cassation opted for the admissibility to apply the protective regime under Art. L. 132-1 of the Code. In the written justification of the judgment, it was indicated that between the insurer and the insured party there subsisted a "bilateral contractual relationship." This relationship, as such, was subject to the review carried out according to Art. L. 132-1 of the Code. ${ }^{167}$ Acceptance of the opinion on the admissibility of application of the protective mechanism under Art. L. 132-1 of the Consumer Code led to the conclusion that between the insured party and the insurer there was a contractual relationship which could be subject

${ }^{165}$ Cass. 1ère civ., 22 mai 2008, D. 2008. Jur. 1954, note D.R. Martin; JCP G 2008. II. 10133; C. Goldie-Genicon: L'assurance..., p. 2447.

${ }^{166}$ Under Art. L. 132-1 of the Code, abusive character is attributed to such contractual provisions which are intended to cause or entail disturbance to the equilibrium of the parties' rights and obligations to the detriment of the non-professional contractual party or consumer. Abusive clauses are considered not included, the contract however remains in force to the exclusion of the clauses found abusive, as long as it may continue to apply without such clauses.

${ }^{167}$ X. Henry: Universalisme de la protection contre les clauses abusives et autonomie du droit de la consummation, In: Des contrats civils et commerciaux aux contrats de consommation. Mélanges en l'honneur du Doyen Bernard Gross. Ed. X. Henry. Nancy 2009, p. 210. 
to the review specific to consumer transactions. ${ }^{168}$ It is significant that such conclusion was accompanied by a statement characteristic of the unitarian conception that the existence of insurance protection is related to a stipulation made for the benefit of the insured party in the contract between the policyholder and the insurer. ${ }^{169}$

This jurisprudence is followed also in the judgment of the Court of Cassation of 13 April 2010, ${ }^{170}$ in which, however, the Court clearly dissociated itself from the assumptions of the unitarian conception.

The judgment was delivered in a situation in which a holder of a payment account acceded to group insurance contracts concluded by the bank for account of its customers. Upon the insured party's death, his heirs sued the bank (group organiser), demanding to be paid the benefits under the insurance contracts. The court of I instance dismissed most claims, allowing, however, the claim for payment to the heirs of the benefit under a life insurance. The appellate court did not share the opinion of the court of I instance and dismissed the suit also in that regard, indicating that the heirs should assert their claims only against the insurer. By challenging the judgment before the Court of Cassation, the appellants argued that their claim against the insurer did not deprive them of the right to sue the bank which, as the policyholder, was to guarantee, in their opinion, due performance of the insurance contract. The argumentation deployed by the appellants was not accepted by the Court of Cassation. In the judgment of 13 April 2010, an opinion was expressed that the bank was not the entity obliged to pay the benefit and that it was not liable for its payment by the insurer. The Court of Cassation explained that accession to a group insurance contract gave rise to a contractual relationship between the insurer and the insured party. The bank, as organiser of the insurance, was a third party vis-à-vis the relationship between the insurer and the insured party. Consequently, the bank was not liable for the insurer's obligations although in the light of Art. L. 141-6 CA it could be treated as the insurer's representative. The Court of Cassation also concluded that between the group organiser [incorrectly referred to as policyholder M.F.] and the policyholder an agreement was indeed concluded but it did not have the features of an insurance contract. It must be added that this was not the first ruling pointing to merely organisational nature of a contract concluded by the policyholder. An analogous opinion

${ }^{168}$ Cf. J. Kullmann: Clauses abusives et contrat d'assurance. "Revue générale du droit des assurances" 1996, p. 11.

${ }^{169}$ Cf. E. Wójtowicz: Kontrola klauzul abuzywnych w prawie francuskim na przykładzie umowy ubezpieczenia. "Rozprawy Ubezpieczeniowe" 2011, No. 11, p. 12.

${ }^{170}$ Cass. Com. 13 avril 2010, n 09-13712. 
was voiced in the judgment of the Court of Cassation of 25 November $1997 .^{171}$

Conviction about a strictly organisational nature of the contract concluded by the policyholder was also reflected in the justification of the judgment of the Court of Cassation of 13 December 2012. ${ }^{172}$ While making a statement in the spirit of the conception of dispersed insurance relationship, the Court of Cassation emphasised that the insured parties are connected with the insurer by a separate contractual insurance law relationship. The parties' freedom of contract is "restricted by the framework agreement (contrat-cadre) negotiated and concluded by the policyholder in the interest of the group."

At this point, it is worth making a few comments on the nature of the insurance framework agreement. It is noticed in the doctrine that framework agreements (especially ones which do not contain essential provisions on the insurance itself) to a large degree remind framework agreements of organisational nature. ${ }^{173}$

An analogous construction was also described in the German science of insurance law. Agreements between the organiser and the insurer on the terms of insurance contracts are referred to, in the German doctrine, as normative agreements (Normenverträg), which should be understood as agreements having as their object the terms of the contracts to be concluded in future. At the first stage, agreement on the terms of the future contracts is reached, which forms a basis for the conclusion, at the second stage, of specific contracts, known as individual (Einzelverträge) contracts, on the terms specified in the basic agreement. ${ }^{174}$

A common feature of preparatory framework agreements is creation of a durable obligational relationship whose essential content is the obligation to conclude final (implementing) contracts on the terms agreed in advance. In case of insurance framework agreements, insurance contracts are concluded by third parties - members of the group. In group insurance, individual insurance contracts, that is the implementing contracts, are a method to concretise performance under the framework agreement both in the objective and subjective aspect.

171 Civ. 1ère, 25 nov. 1997, Revue générale du droit des assurances 1997.1066.

${ }_{172}$ Cass. 2 civ., 13 déc. 2012 no 12-40073, QPC; see J. Bigot in the gloss to the judgment of 13 December 2012, Revue générale du droit des assurances 2013, no 2, p. 251.

${ }^{173}$ M. Orlicki, J. Pokrzywniak: Umowa ubezpieczenia. Komentarz do nowelizacji kodeksu cywilnego, Warszawa 2008, p. 41.

${ }^{174}$ A detailed discussion of the problems of normative agreements with profound analysis of the German doctrine was presented by S. Włodyka: Porozumienia gospodarcze. Warszawa 1978, p. 82 et seq. 
This does not mean, however, that the framework agreement as such merely opens the way for the entry into individual insurance contracts without affecting their content. In insurance transactions, framework agreements are usually composed of the normative part (normativer Teil) and the obligational part (obligatarischer Teil). ${ }^{175}$

The normative part contains framework conditions. In the first place they specify the features and properties that must characterise members of the group covered by insurance protection as well as preconditions to accession to the group. Other questions comprise the scope of insurance protection and specification of various types of risk covered by the insurance contract, the method of calculation of the insurance premium and of its payment. The obligational part defines specific obligations of the group organiser, in particular, efforts to encourage group members to conclude individual agreements and receipt of the declarations of accession and their forwarding to the insurer. The obligations of group organisers are often extended by receipt and collection of insurance premiums and the commitment to administer individual insurance contracts. ${ }^{176}$

In many European countries, it is emphasised that there are no general civil law provisions which would bindingly specify the characteristic (constitutive) features of a framework agreement and clarify - either as mandatory or default rules - its legal regime. It is also difficult to speak of a fully developed, uniform empirical type of framework agreement which would - as established custom - entirely fill that gap. For the above reasons, one should approach with caution the conclusions which are to follow from the mere classification of a given obligational contract as framework agreement; the conclusive factor for the specification of the content of the legal relationship under such contract should be the content of the contract assessed from the point of view of obligational law provisions. This relates also to the determination whether - and, if so, on what conditions - the parties were obliged under such agreement to conclude further implementing contracts or to perform other implementing acts leading to the satisfaction of their final interests, and the scope of the related compensatory liability. ${ }^{177}$

${ }_{175}$ H. Kook: Der Gruppenvertrag in der Kollektivlebensversicherung. Berlin 1939, pp. $15-16$.

${ }^{176}$ F. Herdter: Der Gruppenversicherungsvertrag..., pp. 39-40.

177 See, among others, the judgment of the Polish Supreme Court of 29 March 2016, I CSK 395/16, OSG 2018/5/1. 


\section{Dualistic conception and group insurance}

While sharing the above doubts, certain authors transpose the considerations on the legal nature of the collective insurance contract to another level and focus on the compulsory (assurance à l'adhésion obligatoire) or voluntary (assurance à l'adhésion facultative) character of accession to the insurance contract. ${ }^{178}$

The French Insurance Code, as far as it covers group insurance, does not make a clear distinction between insurance contracts with compulsory and obligatory accession. Nonetheless, the legislator is aware of their existence, as manifest in the provision of Art. L. 141-4 CA. Under this provision, the general rule is that the insured party has the option to withhold consent to an amendment of the terms of insurance protection, which results in that party's withdrawal from the insurance. The insured party, however, does not have such option where the extra-insurance relation between such party and the policyholder renders accession to the insurance compulsory.

The line of distinction between insurance with voluntary accession and insurance with compulsory accession is much clearer under the regime of collective insurance contracts. ${ }^{179}$ In the Mutual Insurance Code (Code de la mutualité) ${ }^{180}$ and the Social Security Code (Code de la Securité sociale), ${ }^{181}$ the definitions of "compulsory" and "voluntary operations" were formulated, which should be understood respectively as insurance with compulsory and voluntary accession. ${ }^{182}$

It should be noted that the division, which was merely sketched by the French legislator, into collective insurance contracts with voluntary and compulsory accession has inspired many representatives of the doctrine and determined one of the dominant directions in the contemporary science of insurance law.

It is indicated that in case of insurance contracts with compulsory accession, insurance protection is afforded under a contract concluded between the policyholder and the insurer. Insured parties enjoy such protection on mere account of their adherence to a specific group. As a result, they may not withdraw from the protection until they forfeit the

${ }^{178}$ Bigot, in: Traité de Droit des assurances. Tome 3..., pp. 131-133; L. Mayaux: La nature juridique de l'assurance collective. In: Les grandes questions du droit des assurances. L. Mayaux. Paris 2011, p. 64.

179 J. Kullmann: Les mécanismes..., pp. 285-286.

180 See Art. L. 221-2 of the Mutual Insurance Code (Code de la Mutualité).

${ }^{181}$ See Art. L. 932-1 of the Social Insurance Code (Code de la Securité sociale).

182 G. Sargos: Le contrat d'assurance..., p. 30. 
status of a group member. The insured parties are not contractual parties to the agreement concluded with the insurer. Therefore, the model of insurance with compulsory accession corresponds to those theoretical assumptions on which the unitarian conception is based. ${ }^{183}$

Analogous position is taken by L. Mayaux, ${ }^{184}$ who pays special attention to the expression by the insured party of the intention to be covered by insurance protection. The author indicates that a collective insurance contract with compulsory accession may be accounted for only by recourse to the assumptions of the unitarian conception. A member of the group does not have to take any steps to establish the insurance protection. Accordingly, one should not search for elements of a declaration of intent in such person's actions. In particular, one may not defend the view that mere adherence to a given group is an expression of applying for insurance protection. Subsistence of the obligation to accede to an insurance may not be identified with the intention to fulfil such obligation. ${ }^{185}$ For example, the obligation to accede to an insurance may follow from adherence to a given occupational class. The fact of obtaining entitlements to undertake gainful work implies only the intention to pursue particular professional activity and not to accede to the insurance.

These observations are consistent with the construction of stipulation of benefit for a third party, by which proponents of the unitarian conception explain the mechanism of establishing protection under the group insurance contract. The right of a third party does not arise in consequence of expression by such party of the intention to take advantage of the stipulation made for the party's benefit. ${ }^{186}$ In the judgment of 13 January 1967, the Court of Cassation held that the expression of intention by a third party to take advantage of the stipulation made for such party's benefit does not give rise to the promising party's obligation to perform. It only affects the possibility to recall the stipulation made for such person's benefit. ${ }^{187}$ This principle corresponds to the solutions adopted in the Insurance Code. In insurance contracts with compulsory accession, the person covered by the insurance may not withdraw from continuation of the insurance in case of amendment to the terms of the afforded protection (Art. 141-4(4) CA).

${ }^{183}$ Ibidem.

${ }^{184}$ L. Mayaux, in: Traité de Droit des assurances. Tome 4..., p. 666.

185 Ibidem.

186 Otherwise in P. Jadoul: La stipulation pour autrui (rapport belge). In: Les effets du contrat à l'égard des tiers. Eds. M. Fontaine, J. Ghestin. Paris 1992, p. 418.

187 Cass., 13 janvier 1967, Pas., 1967, I. p. 571. The up-to-date character of that opinion was confirmed by the Court of Cassation in the judgment of 19 December 2000; see Cass., 19 décembre 2000, Bull. civ. 2000, 1, no 333, p. 215. 
It is indicated that, in case of insurance with voluntary accession, insurance protection follows from the contract between the insurer and a group member. ${ }^{188}$ It is concluded as a result of the declaration of accession and its acceptance by the insurer. The terms of insurance are specified in the framework agreement, between the insurer and the group organiser. Under that agreement, the insurer undertakes at the same time to enter into insurance contracts with members of the group using the abovementioned construction of stipulation of benefit for a third party (stipulation de contrat pour autrui). The person applying for insurance protection makes a declaration of accession to the insurer. Such person consents to being afforded protection on the terms specified by the policyholder and the insurer in the framework agreement. This act may be evaluated as declaration of intent. Therefore, it may serve as ground for the establishment of an obligational relationship which subsists due to the framework agreement but also independent of such agreement. The assumptions of the conception of dispersed obligational relationship apply here in the full extent. ${ }^{189}$

It should be explained that an insurance contract with compulsory accession (assurance à l'adhésion obligatoire) may not be identified with compulsory insurance (assurance obligatoire). ${ }^{190}$ The obligatory character of accession to the insurance contract implies that establishment of the insurance protection is a consequence of adherence to a specific group. Upon fulfilment of the preconditions to adherence to the group, the specific person becomes covered by insurance protection and obtains the status of an insured party. Such person does not have to make any declaration of accession to the insurance. ${ }^{191}$ On the other hand, imposition by the legislator of an insurance obligation does not lead to automatic emergence of insurance protection.

As mentioned above, also in German literature the heterogenous character of the concept of group insurance is emphasised. Authors point to two contractual constructions which account for the system of affording protection to a group of insured parties. These constructions, in fact, display clear affinity with the group insurance models described above in the context of French law. So called improper group insurance (unechte Gruppenversicherung) is based on a framework agreement. The contract from which insurance protection is directly derived is concluded

188 J. Bigot, in: Traité de Droit des assurances. Tome 3..., p. 132; L. Mayaux, in: Traité de Droit des assurances. Tome 4..., p. 666.

${ }^{189}$ L. Mayaux, note sous Cass. 2ème Ch. civ., 8 juillet 2010, no 09-16417, "Revue générale du droit des assurances 2010, no 4, p. 1090.

190 L. Mayaux: La nature juridique..., p. 64.

191 Otherwise in P.G. Marly: Droit des assurances. Paris 2013, p. 285. 
between a group member and the insurer. The group member takes the role of both the policyholder and the insured party. ${ }^{192}$ On the other hand, proper group insurance (echte Gruppenversicherung) ${ }^{193}$ is a construction in which the group organiser is at the same time the policyholder, and the insured parties within the group are not parties to the agreement concluded with the insurer. However, proper group insurance contracts do not form a uniform category. One can differentiate between their two forms.

The first one is automatic group insurance of a variable circle of persons (automatische Gruppenversicherung eines wechselnden Personenkreises). In principle, all members of one group at a given time will be covered by insurance protection against a specific risk without the need to take any independent action. Under this construction, the group is insured in its constantly variable composition. ${ }^{194}$ Therefore, persons who accede to the group specified in the agreement, automatically and without the need to take any action, obtain insurance protection, which they automatically forfeit upon leaving the group. The members covered by a group insurance contract who accede to the contract at a later date are automatically covered by the insurance protection as of the time when they become a part of the group (join the group). ${ }^{195}$ The discussed formula of group insurance is compared in German literature to the construction of so-called current insurance (laufende Versicherungen) governed by the provision of $\S 53 \mathrm{VVG}$. The essence of such insurance boils down to the fact that on the date of conclusion of the agreement, the insurance interest is specified only generally, and the specific risk is covered by the protection only upon its emergence. ${ }^{196}$

The other form of group insurance distinguished in German literature is group insurance of a variable circle of persons with declarations of accession (Gruppenversicherung eines wechselnden Personenkreises mit rechtsbegründende Anmeldung). The essence of this insurance type boils down to the fact that after the conclusion of the insurance contract it is possible for a new group member to make a declaration of accession. The person interested in being afforded insurance protection submits

${ }^{192}$ F. Herdter: Der Gruppenversicherungsvertrag..., p. 14.

193 This terminology was coined by H. Millauer: Rechtsgrundsätze..., pp. $107 \mathrm{ff}$.

194 H. Millauer: Der Gruppenversicherungsvertrag..., p. 19.

195 F. Herdter: Der Gruppenversicherungsvertrag..., p. 23.

196 This type of insurance contract is characteristic of transport insurance and such types of business activities in which both the number and value of goods are subject to constant fluctuation. More in H. Weigel: Niemiecka ustawa o umowie ubezpieczenia Versicherungsvertragsgesetz (VVG) - nowe rozwiazania. "Rozprawy Ubezpieczeniowe" 2008, No. 2, p. 110. 
a declaration of accession to the insurer. This act enables the insurance protection to emerge. The group covered by such protection is not closed as on the date of concluding the insurance contract, but it is possible to accede to and leave the group in case of respectively: acquisition or loss of the properties delimitating the circle of persons belonging to the group of insured parties. ${ }^{197}$

Having regard to the two forms of proper group insurance, as discussed above, one should bear in mind that there are far-reaching differences between this construction and the French model of insurance with compulsory accession when it comes to proper group insurance with automatic accession.

In reference to the discussed constructions, $\mathrm{H}$. Millauer, as the first author in the German doctrine, formulated a definition of group insurance according to which it is a uniform insurance contract covering a group of people to which, in any case, an individual group member belongs either automatically or by accession, but only jointly with the group to which he belongs; under this agreement, the entire group or a single insured party enjoy the same protection against the same risk concerning all the group members subject to the condition that the insurance benefit is paid separately to each insured person within the group. ${ }^{198}$

\section{Conclusions}

A special manifestation of the tendency for the unification of international contract law are the model rules on the insurance contract, better known as the Principles of European Insurance Contract Law (PEICL), developed by the members of the Project Group on a Restatement of European Insurance Contract Law. ${ }^{199}$ As a part of the project, which initially was a typically academic undertaking, an effort was made to create uniform rules on the insurance contract which would make a set of solutions positively evaluated by the representatives of legal science and market participants. It was intended to reach that objective taking

${ }^{197}$ More in F. Herdter: Der Gruppenversicherungsvertrag..., pp. 24-25.

198 So writes H. Millauer: Rechtsgrundsätze der Gruppenvericherung, Karlsruhe 1966, p. 13.

199 M. Lakhan, H. Heiss: An Optional Instrument for European Insurance Contract Law. "Utrecht Journal of International and European Law" 2010, vol. 71, part 27, pp. $1-11$. 
into account the conclusions following from comparative law analysis. Because of the supranational character of the prepared rules, precedence in interpretation of its provisions was afforded to the conception of autonomous construction. ${ }^{200}$

In 2016, the full text of the PEICL was published together with commentary. ${ }^{201}$ The original version of the PEICL did not contain the provisions on group insurance. ${ }^{202}$

As the works progressed, the authors of the PEICL eventually decided to introduce a definition of the group insurance contract which beside the definition of "insurance contract," "damage insurance" and "fixed-sum insurance" - was covered by the provision of Art. 1:201, in paragraph (7) of that provision. It was concluded that group insurance contracts are based on the agreement between the insurer and the group organiser concluded for the benefit of the insured parties who have a common connection with the organiser and meet the requirements set forth in such agreement. So determined circle of the insured parties is referred to as "group." At the same time, the definition expressly mentions the possibility of obtaining protection by members of the insured party's family under the group insurance contract.

Researchers from the Restatement Group opted as well for sanctioning the distinction between insurance with compulsory accession (accessory group insurance) and insurance with voluntary accession (elective group insurance). The first of these concepts is defined as group insurance in which the existence of insurance protection is a consequence of belonging to a given group. The insured party may not withdraw from the insurance coverage. The second category, on the other hand, refers to situations in which accession to a group insurance is a consequence of submitting to the insurer a notice of intention to join the circle of insured parties or absence of refusal to accede to the insurance. ${ }^{203}$

In the provision of Art. 1:201 PEICL, containing a dictionary of terms used in the PEICL, the authors additionally introduced definitions

${ }^{200}$ D. Fuchs: Insurance Restatement jako europejski instrument opcjonalny służacy regulacji umów ubezpieczenia. "RU" 2010, No. 9, p. 132; D. F uch s: Status ubezpieczonego wedtug rozporzadzenia Rady (WE) $\mathrm{nr}$ 44/2001 - wnioski de lege ferenda dla prawodawcy polskiego, "EPS" 2012, No. 5, p. 27.

201 J. Basedow, J. Birds, M. Clarke, H. Cousy, H. Heiss, L. Loacker: Principles of European Insurance Contract Law (PEICL). 2nd expanded ed. Köln 2016. The text was published on the website: https://www.uibk.ac.at/zivilrecht/restatement/sprachfassungen/peicl-en.pdf.

${ }^{202}$ Ch. Armbruester:KPEICL - The Project of a European Insurance Contract Law. "Connecticut Insurance Law Journal" 2013, vol. 20, p. 150.

${ }^{203}$ More on the considered conceptions of the group insurance contract in M. Fras: Umowa ubezpieczenia grupowego. Aspekty prawne. Warszawa 2015, pp. 400-402. 
of the group insurance contract (Art. 1:201 item 7), group insurance with compulsory accession (accessory group insurance) (Art. 1:201 item 8) and group insurance with voluntary accession (elective group insurance) (Art. 1:201 item 9).

At the same time, the authors of the PEICL decided to refer to the person entering into the group insurance contract with the insurer as "group organiser." This term applies regardless of the compulsory or voluntary nature of accession to the group insurance contract. However, the authors did not decide to define that concept under Art. 1:202, which determines the meaning of such terms as "insured" (Art. 1:202 item 1) or "insurance agent" (Art. 1:202 item 5). It must be noted that the authors of the instrument use of the term "group organiser" inconsistently. As a part of the provisions on group insurance contracts, they also make references to the "policyholder" (Art. 18:204 item 2). It seems, however, that the distinction is unintentional and the terms "group organiser" and "policyholder" can be used interchangeably for the purposes of the discussed rules.

There are essential structural differences between insurance contracts to which accession is compulsory and insurance contracts to which accession is voluntary. The insurance contract with compulsory accession (accessory group insurance) is an insurance contract sensu stricto. It is on its basis that individual insured parties obtain insurance protection. However, direct application of the PEICL provisions could result in numerous doubts on account of the special character of group insurance. The authors of the PEICL seem to share such fears. Under the rule expressed Art. 18:201 PEICL, provisions of the PEICL apply only appropriately to insurance contracts with compulsory accession (accessory group insurance).

Economic law analysis implements a research program whose essence was aptly summed up by Gary Backer, one of the leading representatives of the so-called Chicago School, in the title of his Nobel-winning: The Economic Way of Looking at Life ${ }^{204}$. This program assumes that the method of economic analysis may be applied to a full spectrum of social phenomena. This is the case since individuals consequently act in a rational way - driven by an urge to maximise their welfare, wherein that welfare may be understood subjectively. The assumption of individual rationality, in turn, allows to adopt a common methodological basis for social sciences. ${ }^{205}$

${ }^{204}$ G. Becker: The Economic Way of Looking at Life. In: Nobel Lectures, Economics 1991-1995. Ed. T. Persson. World Scientific Co. Singapore, 1997. Available online at the address: http://www.nobelprize.org/nobel_prizes/economic-sciences/laureates/1992/ becker-lecture.html.

${ }^{205}$ Ibidem, especially pp. 38 and 52. 
Therefore, it is possible and desired to apply research tools (quantitative methods, models of market behaviour, etc.) and the conceptual apparatus of microeconomics to the research of law and its evaluation from the point of view of such criteria as utility maximisation, market equilibrium or efficiency. ${ }^{206}$ Moreover, economic law analysis assumes that the supreme value cherished by legislation should be economic efficiency. ${ }^{207}$

Economic analysis of law, which may be found in insurance regulations in the form of an obligation to assess the effects of such regulations, calls in the first place for a review of the quantitative and qualitative significance of group insurance contracts for the insurance market.

It is necessary to track down the reasons behind the popularity of group insurance contracts with a view to identifying the nature of that insurance product and its legal construction. Group insurance is not a simple aggregate of individual insurance contracts. It belongs to a wider category of collective insurance. The essence of group insurance is that it may cover multiple persons belonging to a group identified according to specific criteria, though not necessarily all such persons, and the premium does not have to be paid by the policyholder, so that one contract gives rise to a number of insurance relationships. The differences between group insurance contracts and individual insurance contracts are:

- economic purpose;

- insurable interest (who is interested in insurance protection), which may be very diversified and, consequently, may refer to interests of the policyholder, the insured party and the policy holder, or the insured party;

- sometimes, the sole reason for the conclusion of a group insurance contract is organisational facility;

- type of the benefit rendered to the person covered by insurance protection;

- method of calculating the risk, depending on whether it takes into account individual characteristics of a specific person or features of an abstract group member.

${ }^{206}$ R. Cooter, T. Ulen: Law and Economics. 6th ed. London 2014, pp. 17-54. For more on economic law analysis in Poliash literature, see: R. Stroiński: Wprowadzenie do ekonomicznej analizy prawa law and economics). In: Ekonomia dla prawników i nie tylko. Eds. M. Bednarski, J. Wilkin. Warszawa 2003; R. Stroiński: Ekonomiczna analiza prawa, czyli w poszukiwaniu efektywności. "Kwartalnik Prawa Prywatnego" 3 (2002); J. Stelmach, B. Brożek, W. Zału ski: Dziesięć wykładów o ekonomii prawa. Warszawa 2007, pp. $20 \mathrm{ff}$.

${ }^{207}$ R. Cooter, T. Ulen: Law and Economics..., pp. 7-9. For more on the concept of efficiency in economic law analysis, see. J. Stelmach, B. Brożek, W. Załuski: Dziesięć wykładów..., pp. 25 ff. 


\section{References}

Alter C., Bar S.: Les effects du contrat, Waterloo 2000.

Armbruester Ch.: PEICL - The Project of a European Insurance Contract Law. Connecticut Insurance Law Journal” 2013, vol. 20.

Atamer K.: New Turkish Insurance Contract Law, p. 5, available online at: http://www.aida.org.uk/pdf/Turkish\%20Insurance\%20Contract\%20Law.pdf (accessed: 8.07.2015).

Barthélemy J.: Évolution du droit social: une tendance à la contractualisation mais un rôle accru des droits fondamentaux du travailleur. Paris 2009.

Basedow J., Birds J., Clarke M., Cousy H., Heiss H., Loacker L.: Principles of European Insurance Contract Law (PEICL). 2nd expanded ed. Köln 2016. The text was published on the website: https://www.uibk.ac.at/zivil recht/restatement/sprachfassungen/peicl-en.pdf.

Berdot F.: L'assurance de groupe après les réformes législatives du 31 décembre 1989. "Revue générale des assurances terrestres" 1990.

Bigot J. (ed.): Traité de Droit des assurances. Tome 4. Les assurances de personnes. Paris 2007.

Bigot-Gonçalves M.: Les assurances de groupe. Aix-en-Provence 2009.

Beaugendre S.: Contrat d'assistance et activité d'assurance. Paris 2000.

Boumédienne M.: La place de la loi et du contrat dans la garantie du droit à la protection sociale de 1945 à nos jours, vol. 2. Paris 2003.

Boulay-Paty P.S.: Traité des Assurances et des Contrats à la Grosse D’Émérigon, vol. 1. Paris 1827.

Bourdon V.: La distribution de l'assurance par les associations, contribution à l'étude des assurances collectives. Paris 2002.

Courtieu G.: Assurance des emprunteurs. Garanties collectives et situationes personnelles. Responsabilité civile et assurance 2009.

Cooter R., Ulen T.: Law and Economics. 6th ed. London 2014.

Demarle M.: Le notariat de la prévoyance. Paris 1959.

Demay de Goustine P.: Les problèmes juridiques de l'assurance de groupe. Paris 1977.

Dmochowski S.: Ubezpieczenia majatkowe i osobowe ludności. Warszawa 1975.

Doan O. (ed.): Ubezpieczenia życiowe. Warszawa 1995.

Domagała M.: Zakres i tendencje rozwojowe ubezpieczeń następstw nieszczęśliwych wypadków. „SU” 1975, vol. II.

Fabre A., Lefresne F., Tuchszirer C.: L'accord du 11 janvier 2008 sur la modernisation du marché du travail. Une tentative d'évaluation. "Revue de l'OFCE" 2008, vol. 4, nº 107.

Fontaine M., Ghestin J. (eds.): Les effets du contrat à l'égard des tiers. Paris 1992.

Fras M.: Umowa ubezpieczenia grupowego. Aspekty prawne. Warszawa 2015.

Fuchs D.: Insurance Restatement jako europejski instrument opcjonalny stużcy regulacji umów ubezpieczenia. „RU” 2010, No. 9. 
Fuchs D.: Status ubezpieczonego wedtug rozporzadzenia Rady (WE) nr 44/2001 - wnioski de lege ferenda dla prawodawcy polskiego. „EPS” 2012, No. 5.

Ghestin J., Jamin C., Billiau M.: Traité de droit civil, Les effets du contrat. 3e éd. Paris 2001.

Goldie-Genicon C.: L'assurance de groupe à l'épreuve de la législation sur les clauses abusives. "RD" 2008.

Grau J.B., Chiner N.L., Iglesia J.O.: Insurance law in Spain. Wolters Kluwer 2014.

Groutel H. (ed.) : Traité du contrat d'assurance terrestre. Paris 2008.

Grynbaum L. (ed.): Assurances 2013-2014. Acteurs, contrat, risques des consommateurs, risques des entreprises. Paris 2012.

Grzybowski S. (ed.): System prawa cywilnego. Prawo zobowiazań - część szczegótowa, vol. 3, part 2. Ossolineum 1976.

Handschke J., Kęszycka B., Kowalewski E.: Problematyka grupowych ubezpieczeń na życie w świetle znowelizowanych przepisów k.c. o umowie ubezpieczenia. Spór o intencje ustawodawcy. „Wiadomości Ubezpieczeniowe” 2007, No. 7-8.

Heiss H.: Proportionality in the new German insurance contract act 2008. "Erasmus Law Review" 2012, vol. 5.

Heis s H.: Report of the Commission's Expert Group on European Insurance Contract Law. Part II. Differences in Insurance Contract Laws and Existing EU Legal Framework, http://ec.europa.eu/justice/contract/files/expert_groups/ report_on_section_2_final_en.pdf.

Henry X. (ed.): Des contrats civils et commerciaux aux contrats de consommation. Mélanges en l'honneur du Doyen Bernard Gross. Nancy 2009.

Herdter F.: Der Gruppenversicherungsvertrag: Grundlagen und ausgewählte Problemfelder. Karlsruhe 2010.

Hjalmarsson J.: The Swedish Insurance Contract Act 2005 - an overview. "Nordisk forsikringstidsskrift" 2008, no. 1, pp. 91-92.

Kaufmann S. H.: Governance of occupational pensions in Europe: guaranteed security? Heidelberg 2011.

Koch R.: Insurance Law in Germany. Wolters Kluwer 2018.

Kook H.: Der Gruppenvertrag in der Kollektivlebensversicherung. Berlin 1939.

Kowalewski E.: Prawo ubezpieczeń gospodarczych. Bydgoszcz-Toruń 2006.

Kowalewski E. (ed.): O potrzebie polskiego kodeksu ubezpieczeń. Torun 2009.

Kowalewski E. (ed.): Ubezpieczenia grupowe na życie a prawo zamówień publicznych. Toruń 2011.

Kowalewski E., Wałachowska M.: Nieadekwatność prawa zamówień publicznych do grupowych ubezpieczeń na życie — potrzeba nowych uregulowań prawnych. „Wiadomości Ubezpieczeniowe” 2010, No. 3, pp. 35-36.

Kubiak A.M.: Umowa ubezpieczenia ubezpieczenia na rzecz osoby trzeciej i na cudzy rachunek. Bydgoszcz-Poznań 2008.

Kucharski B.: Przeniesienie praw z umowy ubezpieczenia. Warszawa 2010.

Kullmann J.: Clauses abusives et contrat d'assurance. "Revue générale du droit des assurances" 1996. 
Kullmann J.: Les mécanismes juridiques fondamentaux des assurances collectives. "Revue générale du droit des assurances" 1998, n 3.

Magnusson R.: Gruppenversicherung, insbesondere in der Lebensversicherung in Möller, Winter, Materialien des zweiten Weltkongresses für Versicherungsrecht der internationalen Vereinigung für Versicherungsrecht, Band 5. Karslruhe 1967.

Manes A.: Versicherungs-Lexikon. Berlin 1924.

Mayaux L.: Les grandes questions du droit des assurances. Paris 2011.

Millauer H.: Rechtsgrundsätze der Gruppenvericherung. Karlsruhe 1966.

Montcharmont H.: L'assurance pour compte en matière terrestre. Paris 1931.

Mousseron J.M.: Technique contractuelle. Paris 1999.

Nicolas V.: Essai d'une nouvelle analyse du contrat d'assurance. Paris 1996.

Lakhan M., Heiss H.: An Optional Instrument for European Insurance Contract Law, Utrecht Journal of International and European Law 2010, vol. 71, part 27.

Lambert-Faivre Y., Leveneur L.: Droit des assurances. Paris 2011.

Lamens A.: Les assurances de l'entreprise. Bruxelles 1994.

Landel J.: L'assurance de groupe à la lumière de la jurisprudence récente. "Revue générale des assurances terrestres" 1993, pp. 9-10.

Landel J.: Les mécanismes juridiques de l'assurance de groupe. Ass. Fr. 1983.

Lefebvre L., le Guilcher E.: L'ambigu statut des courtiers grossistes. "Lamy Assurances" 2012, no. 198.

Lar rou met C.: Les obligations, Le contrat. 2e partie, Effets, 6e éd., Paris 2007.

Loacker L.D.: Informed Insurance Choice?: The Insurers Pre-Contractual Information Duties in General Consumer Insurance. Cheltenham 2015.

Łyskawa K.: Grupowe ubezpieczenia na życie z funduszem kapitałowym $w$ systemie zabezpieczenia emerytalnego $w$ Polsce. Warszawa 2007

Orlicki M.: O pojęciu „grupy” w ubezpieczeniach grupowych. „Prawo Asekuracyjne" 2014, No. 1

Orlicki M., Pokrzywniak J.: Umowa ubezpieczenia. Komentarz do nowelizacji kodeksu cywilnego, Warszawa 2008.

Paris C., Dubuisson B. (eds.): Actualités en droit des assurances. Liège 2008.

Persson T. (ed.): Nobel Lectures, Economics 1991-1995. World Scientific Co. Singapore, 1997. Available at the address: http://www.nobelprize.org/nobel_ prizes/economic-sciences/laureates/1992/becker-lecture.html.

Picard M., Besson A.: Les Assurances terrestres en droit français. Le contrat d'assurance, vol. 1. Paris 1975.

Pastre-Boyer A.L.: L'acte juridique collectif en droit privé français. Aix-en -Provence 2006.

Pauffin de Saint Morel M.: L'assurance de groupe. Paris 1977.

Ponge J.C.: Les sanctions en droit des assurances. Paris 2010.

Rapport annuel de la Cour de cassation. Paris 1986.

Rapport Annuel 2009. Les personnes vulnérables dans la jurisprudence de la Cour de cassation. Paris 2009. 
Rigaud D., Baron P., Pignaud X.: Le prévoyance collective des salariés et la loi Evin. "Droit social" 2009.

Rogge J. (ed.): Liber Amicorum René Van Gompel. Diegem 1998.

Rogge J., Regout M., Longfils F. (eds.): Liber amicorum Jean-Luc Fagnart. Louvain-la-Neuve 2008.

Roueil E.: Essai sur le contrat d'assurance collective. Orléan 1998.

Saint-Hilaire P.D.: Le tiers à l'acte juridique. Paris 2000.

Sargos G.: Le contrat d'assurance de personnes et ses trois principaux codes: analyse comparative et prospective. Paris 2012.

Schwartz B. (ed.): The Code Napoleon and the Common-Law World. New Jersey 1998.

Serwach M., Kliszcz J.: Grupowe ubezpieczenie na życie w świetle prawa, doktryny i praktyki ubezpieczeniowej. „Prawo Asekuracyjne” 2010, No. 2.

Stelmach J., Brożek B., Załuski W.: Dziesięć wykładów o ekonomii prawa. Warszawa 2007.

Stroiński E.: Ubezpieczenia na życie. Teoria i praktyka. Warszawa 2003.

Szczepańska M.: Ubezpieczenia na życie. Aspekty prawne. Warszawa 2008.

Szymański Z.: Ubezpieczenia następstw nieszczęśliwych wypadków. Warszawa 1980.

Tauran T.: Les Assurances. Paris 2004.

Weigel H.: Niemiecka ustawa o umowie ubezpieczenia - Versicherungsvertragsgesetz (VVG) - nowe rozwiazania. Rozprawy Ubezpieczeniowe 2008, No. 2.

Warkałło W.: Prawo ubezpieczeniowe. Zarys wykładu i materiały normatywne. Warszawa 1974.

Wąsiewicz A. (ed.): Ubezpieczenia $w$ gospodarce rynkowej, vol. 1. Bydgoszcz 1994.

Wieser A.: Gruppenversicherungen. Wien 2006.

Wójtowicz E.: Kontrola klauzul abuzywnych w prawie francuskim na przyktadzie umowy ubezpieczenia. „Rozprawy Ubezpieczeniowe” 2011, No. 11. 